\title{
Review \\ Biocides as Biomedicines against Foodborne Pathogenic Bacteria
}

\author{
Eugenia Butucel 1,2, Igori Balta 1,2,3, Mirela Ahmadi ${ }^{2}$, Gabi Dumitrescu ${ }^{2}$, Florica Morariu ${ }^{2}$, Ioan Pet ${ }^{2}$, \\ Lavinia Stef $2, * \mathbb{D}$ and Nicolae Corcionivoschi $1,2, * \mathbb{D}$
}

1 Bacteriology Branch, Veterinary Sciences Division, Agri-Food and Biosciences Institute, Belfast BT4 3SD, UK; eugenia.butucel@afbini.gov.uk (E.B.); igor.balta@afbini.gov.uk (I.B.)

2 Faculty of Bioengineering of Animal Resources, Banat University of Animal Sciences and Veterinary Medicine-King Michael I of Romania, 300645 Timisoara, Romania; mirelaahmadi@usab-tm.ro (M.A.); gdumitrescu@animalsci-tm.ro (G.D.); floricamorariu@animalsci-tm.ro (F.M.); ioanpet@eurofins.com (I.P.)

3 Faculty of Animal Science and Biotechnologies, University of Agricultural Sciences and Veterinary Medicine, 400372 Cluj-Napoca, Romania

* Correspondence: lavi_stef@animalsci-tm.ro (L.S.); nicolae.corcionivoschi@afbini.gov.uk (N.C.)

check for updates

Citation: Butucel, E.; Balta, I.; Ahmadi, M.; Dumitrescu, G.; Morariu, F.; Pet, I.; Stef, L.; Corcionivoschi, N. Biocides as Biomedicines against Foodborne Pathogenic Bacteria. Biomedicines 2022, 10, 379. https://doi.org/ 10.3390/biomedicines10020379

Academic Editor: Célia F. Rodrigues

Received: 13 January 2022 Accepted: 31 January 2022 Published: 4 February 2022

Publisher's Note: MDPI stays neutral with regard to jurisdictional claims in published maps and institutional affiliations.

Copyright: (C) 2022 by the authors. Licensee MDPI, Basel, Switzerland. This article is an open access article distributed under the terms and conditions of the Creative Commons Attribution (CC BY) license (https:// creativecommons.org/licenses/by/ $4.0 /)$.

\begin{abstract}
Biocides are currently considered the first line of defense against foodborne pathogens in hospitals or food processing facilities due to the versatility and efficiency of their chemical active ingredients. Understanding the biological mechanisms responsible for their increased efficiency, especially when used against foodborne pathogens on contaminated surfaces and materials, represents an essential first step in the implementation of efficient strategies for disinfection as choosing an unsuitable product can lead to antibiocide resistance or antibiotic-biocide cross-resistance. This review describes these biological mechanisms for the most common foodborne pathogens and focuses mainly on the antipathogen effect, highlighting the latest developments based on in vitro and in vivo studies. We focus on biocides with inhibitory effects against foodborne bacteria (e.g., Escherichia spp., Klebsiella spp., Staphylococcus spp., Listeria spp., Campylobacter spp.), aiming to understand their biological mechanisms of action by looking at the most recent scientific evidence in the field.
\end{abstract}

Keywords: biocides; biomedicines; disinfection; antibiotic-biocide cross-resistance; foodborne pathogens

\section{Introduction}

Foodborne pathogens are of major importance to public health due to their ability to cause severe diseases and death in humans, emphasizing the need for constant monitoring and prevention [1]. Because of their ability to proliferate in food and water, foodborne infectious agents are a major concern for the food industry, consumers, and medical and veterinary practices [2]. Controlling their proliferation can be impaired by the acquisition of resistance mechanisms, via gene mutations or plasmid-encoded resistance, leading to the so-called targeted resistance, as unlike antibiotics biocides are able to directly target biological structures or mechanisms within the bacterial cell (e.g., membrane permeability or biocide efflux) [3]. The increased ability of pathogen proliferation within the host and the acquisition of resistance to biocides are two factors that are increasingly associated with nosocomial infections, representing a significant burden for the global health systems. The effects include high mortality and morbidity rates, high treatment costs, diagnostic uncertainties, and a lack of confidence in medicine [4]. According to the World Health Organization, the recently announced group of emerging pathogenic agents, ESKAPE, includes both Gram-positive and Gram-negative microorganisms (e.g., Staphylococcus aureus, Klebsiella pneumoniae, Pseudomonas aeruginosa) which are the common causes of life-threatening nosocomial infections in humans $[5,6]$. A major reservoir of such pathogens is the farming industry, where they have the capacity to form biofilm and become biocidaland antibiotic-resistant. 
The availability of efficient disinfection procedures is a critical element of the entire biosecurity programs designed to prevent and eliminate a wide diversity of life-threatening pathogens in agriculture, healthcare, and food industry facilities. These antipathogen chemicals, displaying bactericidal or bacteriostatic effects, are called biocides. They can be defined as broad-spectrum anti-infective application products, including disinfectants, preservatives, and agents to prevent microbial growth [7]. Biocides are classified as substances and preparations containing one or more active blends of substances to destroy, prevent the development of, or control any harmful microorganism via chemical or biological activities [8,9]. Recent developments allowed the inclusion of biocidal chemicals as composites in various articles, such as surgical scrubs, medical devices, mouthwashes, wound dressings, and antibacterial soaps [10].

By definition, most biocides can be toxic to some form of living organisms, with toxicity manifested as direct cytotoxicity, systemic direct or indirect toxicity, and allergenic activity leading to oxidation or solubilization of the lipids in the cell wall. The mechanism of biological action differs depending on the chemical substance, the presence (synergism) or absence of other chemicals, and the type of microorganism to be eradicated or attenuated. Some of the possible examples of mechanisms of action of biocidal antimicrobial substances are considered to cause oxidation of lipids from the membrane surface, which subsequently causes lesions and disturbance of transport and enzymatic activity [11-13].

Numerous reports mention the possibility of antibiotic-biocide cross-resistance in pathogenic bacteria [14-17]. This emphasizes the fact that indiscriminate use of these substances and contamination of both water and soil environments are leading to uncontrolled release of biocides into the environment and the potential of bacterial resistance occurrence [18]. For example, the attachment of bacteria to different surfaces (e.g., industrial, hospitals, and medical devices) leads to biofilm formation, posing a serious threat to human health or to biosecurity in various industries. Ineffective disinfection of surfaces and improper use of biocides can lead to the survival of bacteria and viruses, often contributing to the transmission of infectious agents $[19,20]$. The biocidal resistance of planktonic cells has been attributed to gene mutations or changes in the cellular envelope, activation of the efflux pump, or expression of enzymes that cause biocide degradation [21].

Consequently, the developed bacterial tolerances initiated a search for biocides derived from natural sources, including plants, peptides, enzymes, or even nanotechnology fabrication of novel biocidal products [22]. This review will successively consider the different compounds used as biocides and their mechanisms of action, before successively presenting their effects on the main emerging pathogens. Our approach in this review was to bring together clusters of scientific data on the efficient applications of biocides for sanitation and disinfection purposes to combat bacterial foodborne pathogens in different settings.

\section{Biocides}

\subsection{Metal-Based Biocides}

Metal-based disinfectants (e.g., heavy metals) are often used as chemotherapeutic agents to prevent infections in humans and animals [23]. Among these, metal cations and oxyanions are well known for their antimicrobial effects, especially for their toxicity towards most biofilm-forming bacteria [24]. As for all the other biocides, the ability of bacteria to develop resistance to metals must be one of the main priorities during the developmental process as they have the ability to co-select for antibiotic-resistant bacteria which could reduce their ability to prevent or eradicate biofilms [25]. This mechanism of acquired resistance is involved in the transfer of antibiotic resistance genes, especially if the metal-biocide genes are located on the same plasmid [26]. One example is pyridoxine, which was proven to have an antibiofilm effect when tested against $S$. aureus and S. epidermidis biofilms, leading to complete eradication at concentrations of 64 and $16 \mu \mathrm{g} / \mathrm{mL}$ [27]. Another example of efficient antibiofilm metal-based biocides is silver nanoparticles, which in combination with ammonium salts have been shown to eradicate bacterial biofilms [28]. In this case, the ammonium salts play the role of a facilitator of drug diffusion into the biofilm [29], a 
role also emphasized in a more recent study [30]. The biology and mechanisms of action of metal-based biocides were very recently reviewed, and their role in treating bacterial infections was emphasized especially in the case of antibiotic resistant bacteria [31]. Further details on their biological mechanisms of actions are included in Tables 1-4.

\subsection{Aldehydes, Alcohols, Phenols, and Bisphenols}

Formaldehyde, occasionally used in veterinary hygiene, interacts with bacterial proteins, DNA, and RNA by crosslinking free amino groups specifically at low temperature, which is considered an efficient method for the disinfection and sterilization of surgical equipment. The interaction is associated with the alkylation of sulfhydryl and amino groups from proteins and the alkylation of the ring-nitrogen atoms belonging to purine nucleotide bases which inhibit transport mechanisms [32]. Phenolic compounds, on the other hand, have a wider spectrum of activity against bacteria and also fungi and viruses. One of the most common bisphenols is triclosan (TCS), a compound used in the preparation of antiseptic soaps and widely used in industries, being incorporated into various products such as toys, deodorants, toothpaste, and cosmetics $[33,34]$. The bactericidal mechanism of action of phenols and bisphenols occurs via the disruption of the cytoplasmic membrane, which leads to a rapid release of intracellular components. TCS has a specific target, enoyl-ACP reductase in bacteria, encoded by the fabI gene, involved in fatty acid synthesis [35]. Phenol (carbolic acid) is one of the old and classical antiseptic agents with a prominent fungicidal and bactericidal activity that can be improved with the addition of EDTA and warmer temperatures [32]. On the other hand, low temperatures, lipids, and higher alkalinity can diminish and considerably affect its biocidal properties [9]. On the other hand, low temperatures, lipids, and higher alkalinity can diminish and considerably affect its biocidal properties [9].

\subsection{Halogens, Peroxides, and Organic Acids}

Halogenic compounds (e.g., hypochlorite; iodophor; iodine-, bromine-, and chlorinecontaining compounds) can oxidize proteins within a cell, penetrate the cellular membrane, and cause the interruption of the oxidative phosphorylation systems [32,36]. The peroxidebased biocides (e.g., peroxyacetic acid and hydrogen peroxide) on the other hand are mainly used for disinfection of surfaces (metallic, glass, or plastic), with high efficacy against bacterial and viral pathogens [37]. Organic acids (e.g., lactic, acetic, and citric acids) are also commonly used as biocides by inclusion in food as preservatives and are considered to exhibit antimicrobial action through $\mathrm{pH}$-mediated coagulation of proteins [37]. Recent studies indicated that natural antimicrobial formulations enriched with organic acids demonstrated a strong ability to reduce bacterial attachment to chicken skin and carcasses during the washing process $[9,20]$.

\subsection{Quaternary Ammonium Compounds (QACs)}

Quaternary ammonium compounds (e.g., alkyl trimethylammonium bromides (cetyltrimethylammonium bromide, dialkyl dimethylammonium chloride, and didecyldimethylammonium chloride), benzalkonium chloride, Miramistin, cetylpyridinium chloride, octenidine dihydrochloride, twin/gemini surfactants) are some of the most used disinfectants and antiseptics in different fields, including households, agriculture, industry, and medicine [38]. Some of the antipathogenic roles of QACs include $\mathrm{pH}$ modification and the induction of damage of cellular membranes causing disruption [32]. Benzalkonium chloride (BAC) and cetrimide are the two main agents in the QAC group that are active against the coverings contaminated by bacteria, viruses, and fungi. They are normally used to disinfect areas where animals are kept and transported (e.g., floors, walls, and transport vehicles) and are also used to disinfect food-handling areas. In bacteria, the main target for QACs is the cytoplasmic membrane. BAC can bind to anionic sites on the outer surface of bacteria that cause destabilization and solubilization of cells and can disintegrate proteins, enzymes, and nucleic acids [39]. 


\subsection{Phytochemicals}

Phytochemicals are considered an unexploited source of new biocides [40]. Plant extracts show a promising biocidal potential among the alternative treatments to be investigated, with many advantages over traditional synthetic options. They are environmentally friendly (biodegradable) and have a functional complexity (preventing bacterial resistance transmission). Plants can synthesize many organic compounds classified as primary and secondary metabolites. The possible advantage of these substances is that they express a significantly lower number of side effects when compared to the case of the use of synthetic chemical substances as they undergo detoxification and are poorly absorbed with rapid excretion [41]. New formulations of antimicrobial mixtures, including combinations of organic acids and plant extracts, were proven in in vitro and in vivo studies to have more efficient antimicrobial activity against different pathogens by acting directly or indirectly against their principal virulence factors [22], as we describe below.

\section{Biological Mechanisms of Action of Biocides}

The processes involved in biocide antimicrobial activity include the transport of the antimicrobial agent to the cell surface, adhesion, invasion, diffusion, penetration, and interaction at the target site (Figure 1). Of course, these processes are not instantaneous, and their action in time may differ depending on the biocide agent. The differences also refer to their mode of action, their chemical composition, and the physicochemical properties of each biocide [42]. The colloquial definition of an antimicrobial effect is related to the interaction between an active substance and specific targets of the microbial cell. The critical characteristics of these interactions are the physicochemical properties of the biocide, the morphology of the cells, and the physiological state of the microorganism [43].

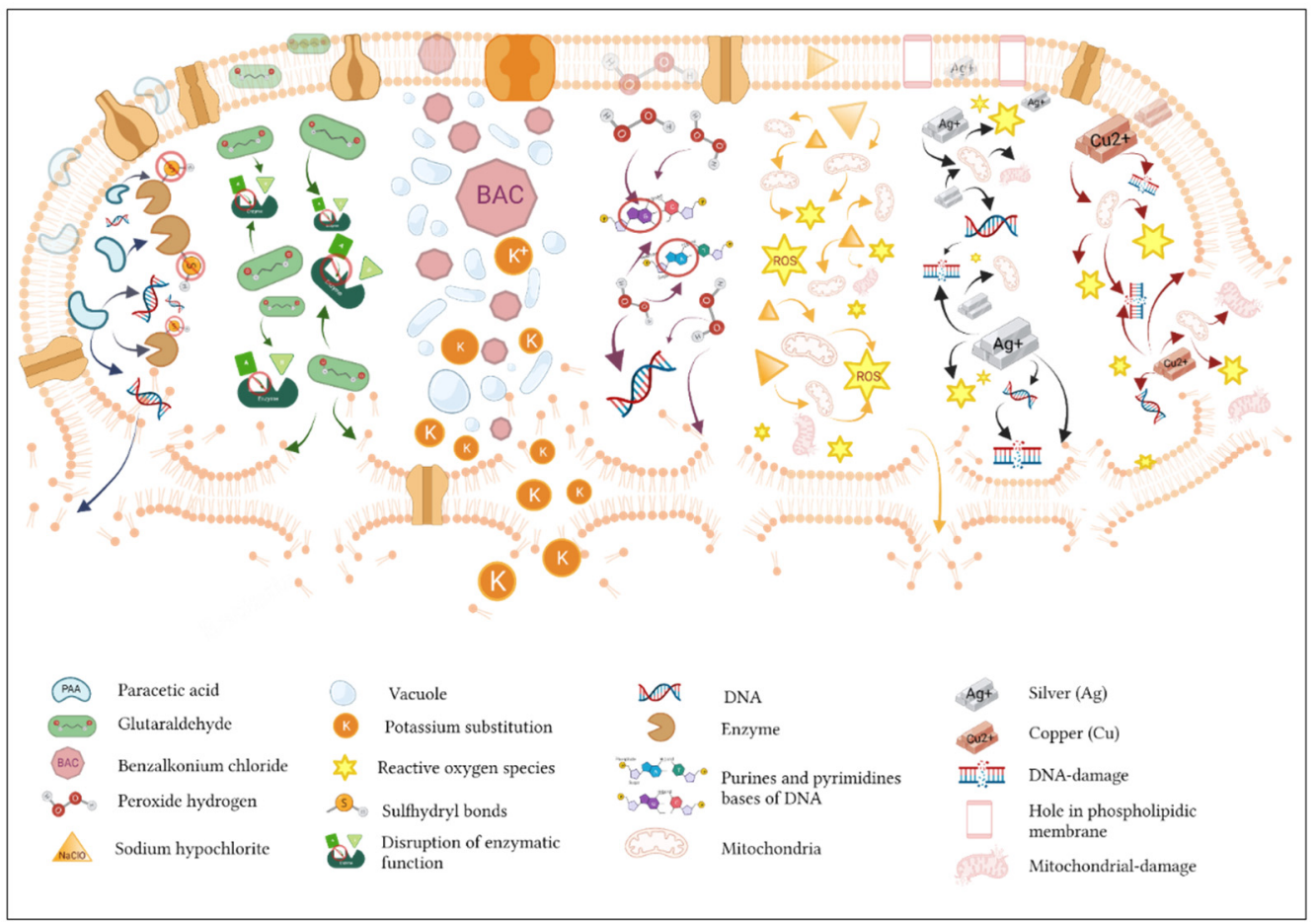

Figure 1. Biocides and their main modes of action. Peracetic acid triggers the oxidation of sulfur and sulfhydryl bonds of enzymes and proteins, causing cell wall disruption leading to lipoprotein blockage in the cytoplasmic membrane and generation of peroxide radicals. Glutaraldehyde favors cross-binding with the amine-presenting lipids of bacterial cells and inhibits the transport of enzymes and functions by inducing a bactericidal effect. Benzalkonium chloride induces destabilization of the membrane permeability and vacuolation, modifies the $\mathrm{K}^{+}$intake, and induces cell surface rupture and extravasation of the cellular content. Hydrogen peroxide enables passive diffusion, penetrates 
the membrane, and targets the DNA and mainly the purine bases (guanine and adenine). Sodium hypochlorite stimulates ROS formation and cell membrane rupture. Silver (Ag) mainly affects phospholipids and creates holes in the outer membrane by increasing permeability, causing disruption of the breathing cycle that leads to ROS formation and DNA damage. Copper $(\mathrm{Cu})$ is prone to ROS formation, which causes irreversible changes to DNA and inflicts damage to the membrane, causing loss of intracellular components and finally cellular death.

Although the mechanisms at the origin of the biocidal effects vary according to the compounds because of their structure, their consequences at the biofilm scale lead to a succession of similar steps. Typical antibacterial events include the following [44]: (i) inhibition of respiration or inhibition of catabolic/anabolic pathways, (ii) destabilization of membrane integrity that leads to the leakage of essential intracellular constituents, (iii) the disruption of the motor force of the transmembrane proton that leads to a decoupling of oxidative phosphorylation and the inhibition of active transport on the membrane, (iv) lysis, (v) interruption of replication, and (vi) coagulation of the intracellular material.

\subsection{Release-Killing Biocides and Contact-Killing Biocides}

"Release-killing" biocides are incorporated on surface coatings in order to allow their constant release into the environment and to kill nearby bacteria. These types of biocidal products may contain antibiotics, metal nanoparticles (e.g., $\mathrm{Ag}^{+}$and $\mathrm{Cu}^{2+}$ ), nitrogen oxides, and other substances. Their mode of action can include inhibition of DNA replication or protein synthesis, destruction of the cell membrane, and the capacity to inactivate metabolic enzymes and deteriorate other important proteins [45,46]. Unlike the releasekilling biocides, the "contact-killing biocides" are permanently immobilized by physical or chemical interactions on the surface. Biocides used for this purpose can be assembled from natural biomacromolecules (e.g., chitosan, antibacterial peptides (AMPs)), antibacterial enzymes (AMEs), nylon polymers, and others [47-50]. These compounds and polymers are based on a strong electrostatic interaction between positively charged groups and negatively charged phospholipids on the bacterial cell membrane, which leads to general disturbances of the lipid bilayer and leakage of proteins and other intracellular components [51]. In addition, some AMEs may catalyze the degradation of polysaccharides across the cell membrane or suppress quorum sensing, triggering bacterial death [52]. For N-halamines, direct transfer of active halogen to bacteria may inhibit their metabolic process [53]. The main difference between the "release-killing" and the "contact-killing" biocides resides in the fact that the latter are considered less efficient in inducing pathogen resistance [54].

\subsection{Biocide Efficacy}

The effectiveness of a disinfection procedure is dependent on the correct application of an effective biocide. However, inefficiency can have multiple explanations, and bactericidal resistance is one example. There are several reasons for the loss of effectiveness in a disinfection procedure that are easy to confuse with acquired resistance, including inefficient application, prolonged application, inefficient contact with the pathogen, and low availability [55]. Biocidal resistance describes the relative insensitivity of a microorganism to a particular treatment under a certain set of conditions [56]. It is usually quantified as the concentration that causes sublethal effects in addition to biocide resistance which can be a natural property of a microorganism or acquired through mutation or the acquisition of self-replicative plasmids [57]. According to the Weibull model, the bacterial population can be divided into subgroups with different death rates (e.g., very sensitive, sensitive, and resistant cells). Interestingly, at higher concentrations the antimicrobial effects are easily induced; however, most bacteria are tolerant at low concentrations, most possibly due to intrinsic defense mechanisms [19].

\subsection{Inducing the Coresistance and Tolerance of Microorganisms through the Use of Biocides}

The excessive use of biocides and antibiotics has a considerable economic and environmental impact, and inappropriate use of more assertive biocides and high doses (as far 
as overcoming resistance) poses an additional risk to public health [22]. Reduced susceptibility of microorganisms to biocides can be achieved by mutation or acquiring a plasmid or a transposon [58]. Acquired resistance to antibiotics also occurs through mutations or acquiring genetic elements through plasmids and transposons [59]. The acquired resistance can result in bacteria being able to grow in a biocide-antibiotic concentration that increases gradually, leading to the so-called acquired coresistance. However, this temporary resistance to phenotypic adaptation is unlikely to play an important role in determining the long-term survival of bacteria in biocides [55].

As a promising alternative strategy in the control of cross-resistance, the combined chemotherapy of two or more anti-infective compounds (synergism) has been prominently employed to treat complex infections, including respiratory diseases, which often involve viral and bacterial strains [60]. Research is extensively focused on applying chemical substances that act on various bacterial targets, including adhesins, bacterial toxins, and quorum sensing (QS) signaling [61]. The constant administration of anti-infective compounds has raised questions about the positive selection of resilient bacterial strains [62]. The mechanisms involved in these processes are not fully understood and are yet to be elucidated. To date, the mechanism of action was associated to bacterial resistance to anti-infective agents and include membrane adaptation [63]; changes in the expression of enzymes, inducers, and repressor genes; and horizontal transfer of resistance genes [64], including those involved in biofilm formation [65] and QS signaling. In a recent study realized by Sonbol et al. [63], adaptation processes of E. coli isolates treated with sublethal concentrations of triclosan were described. A decrease in membrane permeability (outer and inner) and depolarization and an increase in the negative potential was observed. Moreover, triclosan was found to be a substrate for efflux pump expression in bacterial strains, and overexpression in efflux activity was observed in E. coli strains [63].

\section{The Effect of Biocides against Foodborne Pathogenic Bacteria}

\subsection{Escherichia spp.}

Several Escherichia species are natural residents of the intestinal microbiota, but pathogenic species also cause urinary tract infections and the dysbiosis of the reproductive tract [66]. For example, clinically relevant E. coli O157:H7 was involved in serious waterborne and foodborne outbreaks leading to severe human infections of the gastrointestinal tract and hemolytic uremic syndrome [22,67]. As such, access to clean, germ-free water is essential, but water contamination remains a global concern. As a consequence assembling a filter with biocidal properties to purify drinking water could be a way to eliminate pathogenic E. coli. Water treatments with semipermeable membrane filters have been advanced significantly in recent years, and techniques may include microfiltration, ultrafiltration, and nanofiltration, providing removal of harmful microorganisms [68]. The advantages of membrane filtration are due to increased efficiency and low energy consumption; moreover, filters are environmentally friendly, compact, and easy to maintain [69]. An example of a cellulosic filter combined with butane tetracarboxylic acid (BTCA) and glutaraldehyde was recently described [13]. The results indicated that glutaraldehyde solution or 1,2,3,4-butanetetracarboxylic acid (BTCA) added to cellulose pretreated with cationic polyacrylamide (C-PAM) increased antimicrobial activity against $E$. coli, an effect apparently caused by glutaraldehyde interaction with the nonprotonated amines from the outer layer of the bacterial cell, leading to disruption of bacterial enzymatic activity.

In planktonic and biofilm states [70], sodium hypochlorite (SH) showed the fastest biocidal action, while NaDCC (chlorine-based biocide) showed the highest antimicrobial rate but with lower efficiency. The biofilm assay demonstrated that such biocides caused logarithmic declines by approximatively $>3.20 \log \mathrm{CFU}$ per $\mathrm{cm}^{-2}$, possibly due to the production of reactive oxygen species (ROS). The authors demonstrated that neutral electrolyzed oxidizing water (NEOW) displayed the most extended decay time for total chlorine loss $\left(70\right.$ days at $\left.5{ }^{\circ} \mathrm{C}\right)$, possibly because it allowed the highest formation of reactive oxygen species (ROS). NEOW also had the most reduced chlorine loss rate $(0.013 \mathrm{ppm} / \mathrm{min}$ at 
$5{ }^{\circ} \mathrm{C}$ ), suggesting this biocide as a suitable alternative to $\mathrm{SH}$ biocides, which showed the most increased chlorine loss rate $\left(0.025 \mathrm{ppm} / \mathrm{min}\right.$ at $\left.5^{\circ} \mathrm{C}\right)$ [38].

The novel pyridoxine-based quaternary ammonium derivatives from terbinafine [11] had an in vitro antimicrobial activity of $8 \mu \mathrm{g} / \mathrm{mL}$ MIC against E. coli (MG1655). The MIC values are caused by a dual antimicrobial molecular mechanism, described as bimodal, which integrates the ability to induce membrane integrity damage and targeting of pyridoxal-dependent enzymes. Other engineered peptidic biocides, synthesized from 45 indolicidin analogs [71], displayed MICs of $2.7 \mu \mathrm{g} / \mathrm{mL}$ for E. coli ML-35p, $2.5 \mu \mathrm{g} / \mathrm{mL}$ for E. coli M17, and $1.8 \mu \mathrm{g} / \mathrm{mL}$ for E. coli 25293. The authors indicated that the possible biocidal mechanism of action occurs due to the disruption of the cell membrane and is mainly conditioned by the amphipathicity and hydrophobicity of indolicidin molecules.

Of the newest disinfectants, the electrochemically activated solutions (ECASs) have attracted significant interest due to their environmentally friendly nature and the persistence of different oxidants with a more elevated disinfection prospect when compared to chlorine-based biocides [72]. The authors of a recent study concluded that ECASs are promising biocides with different chemical reactive oxidative species capable of rendering microorganisms inefficient at optimal concentrations and changing their molecular ionic structure [72]. The inactivation kinetics with different concentrations (1\%, 5\%, and 10\%) indicated that E. coli exhibited a maximum $3.50 \log C F U / \mathrm{mL}$ reduction and was more vulnerable to ECASs than Aeromonas spp.

Table 1. Biocides and their impact on Escherichia coli.

\begin{tabular}{|c|c|c|c|c|c|}
\hline Biocide & Strain & Concentration & Mechanism/Notes & Gene/Protein & Ref. \\
\hline $\begin{array}{l}\text { MBQ (magnetic } \\
\text { biochar/quaternary } \\
\text { phosphonium salt) }\end{array}$ & $\begin{array}{l}\text { E. coli ATCC } \\
25922\end{array}$ & MBC 20 mg/L & $\begin{array}{c}\text { Cell wall and membrane penetration; } \\
\text { induced vacuolization, loss of cell } \\
\text { integrity/permeability, leakage of } \\
\text { intracellular components, oxidative } \\
\text { stress. }\end{array}$ & n.i. & {$[73]$} \\
\hline $\begin{array}{l}\text { Cellulose foam paper with } \\
\text { BTCA and GA }\end{array}$ & E. coli MTCC 40 & $\mathrm{MIC} 1 \mathrm{~g} / \mathrm{L}$ & $\begin{array}{l}\text { BTCA-crosslinking agent. Reduced } \\
\text { pH and growth. GA-cross-binding } \\
\text { with cell wall amines interfered with } \\
\text { the transport and enzymatic activities } \\
\text { and bactericidal effect. }\end{array}$ & n.i. & [13] \\
\hline $\begin{array}{l}\text { Polyvinylidene fluoride } \\
\text { membranes with guanidine } \\
\text { backbone or sulphonium } \\
\text { backbone }\end{array}$ & $\begin{array}{l}\text { E. coli ATCC } \\
25922\end{array}$ & & $\begin{array}{l}\text { Bacteria lost structural integrity caused } \\
\text { by the existing electrostatic interactions, } \\
\text { which led to the leakage of intracellular } \\
\text { components and caused their death. }\end{array}$ & n.i. & [12] \\
\hline $\begin{array}{l}\text { Sodium hypochlorite; } \\
\text { chlorine dioxide; neutral } \\
\text { electrolyzed oxidizing water; } \\
\text { sodium dichloroisocyanurate }\end{array}$ & E. coli CECT 434 & $\begin{array}{c}\text { MBC } 80 \text { and } \\
100 \text { ppm-planktonic } \\
\text { cultures; } \\
50 \text { ppm-biofilms }\end{array}$ & $\begin{array}{l}\text { ROS production in the case of } \mathrm{SH} \text { and } \\
\text { NEOW. }\end{array}$ & n.i. & [38] \\
\hline $\begin{array}{l}\text { KFU-127 (pyridoxine-based } \\
\text { quaternary ammonium } \\
\text { derivatives of terbinafine } 127 \text { ) }\end{array}$ & E. coli MG1655 & $\begin{array}{l}\mathrm{MIC} 8 \mu \mathrm{g} / \mathrm{mL} \\
\mathrm{MBC} \times 16\end{array}$ & $\begin{array}{l}\text { Cell membrane damage and membrane } \\
\text { potential changes; inhibitory property } \\
\text { on pyroxidal-dependent enzymes. }\end{array}$ & n.i. & {$[11]$} \\
\hline $\begin{array}{l}\text { Peptide biocides ( } 45 \text { analogs } \\
\text { of antimicrobial peptide } \\
\text { indolicidin) }\end{array}$ & $\begin{array}{l}\text { E. coli M17; E. coli } \\
\text { ATCC } 252934\end{array}$ & $\mathrm{MIC} 0.9-1.8 \mu \mathrm{g} / \mathrm{mL}$ & $\begin{array}{l}\text { Pore-forming agents; the introduction } \\
\text { of groups } \mathrm{Cl}, \mathrm{NO}_{2}, \mathrm{~F} \text { into the aromatic } \\
\text { ring in the structure of biocides leads to } \\
\text { increased antimicrobial activity; } \\
\text { analogs with higher hydrophobicity } \\
\text { have the possibility of breaking the cell } \\
\text { membrane. }\end{array}$ & n.i. & {$[71]$} \\
\hline $\begin{array}{l}\text { PAA (peracetic acid) } \\
\text { PFA (performic acid) }\end{array}$ & $\mathrm{Amp}^{\mathrm{R}}$ E. coli & $\begin{array}{l}\text { MIC } 80 \text { and } \\
60 \mathrm{mg} \mathrm{min} / \mathrm{L} \\
10 \text { and } 15 \mathrm{mg} \mathrm{min} / \mathrm{L}\end{array}$ & $\begin{array}{l}\text { Oxidation of sulfur and sulfhydryl } \\
\text { bonds in proteins and enzymes; } \\
\text { disruption/dislodging the cell walls } \\
\text { and modifying the cytoplasmic } \\
\text { membrane of lipoproteins, blocked } \\
\text { enzymatic and transport processes; } \\
\text { formation of hydroxyl peroxide free } \\
\text { radicals. }\end{array}$ & n.i. & [74] \\
\hline
\end{tabular}


Table 1. Cont.

\begin{tabular}{|c|c|c|c|c|c|}
\hline Biocide & Strain & Concentration & Mechanism/Notes & Gene/Protein & Ref. \\
\hline PMA (permaleic acid) & $\begin{array}{l}\text { E. coli ATCC } \\
25922\end{array}$ & $\begin{array}{l}\text { MIC } 40 \mathrm{mg} / \mathrm{L}(50 \%) \\
100 \mathrm{mg} / \mathrm{L}(100 \%)\end{array}$ & $\begin{array}{l}\text { Damage and disruption of cell } \\
\text { membrane activity. }\end{array}$ & n.i. & {$[75]$} \\
\hline $\begin{array}{c}\text { ECASs }(1 \%, 5 \%, 10 \%) \\
\text { (electrochemically activated } \\
\text { solutions) }\end{array}$ & $\begin{array}{l}\text { E. coli from the } \\
\text { water disruption } \\
\text { network of } \\
\text { NUST }\end{array}$ & & $\begin{array}{l}\text { Oxidizing agent; induced damage to } \\
\text { the cell membrane; } \mathrm{Cl} \text { in ECASs } \\
\text { increased cell permeability and } \\
\text { disrupted protein synthesis; } \\
\text { degradation of functional groups } \\
\left(\mathrm{ClO}_{2}, \mathrm{H}_{2} \mathrm{O}_{2} \text {, ozone }\right) \text { over time } \\
\text { weakens oxidative stress. }\end{array}$ & n.i. & {$[72]$} \\
\hline $\begin{array}{l}\text { AuNSps (nanosphere) } \\
\text { AuNSts (nanostars) } \\
\text { AuNCs (nanocubes) }\end{array}$ & $\begin{array}{l}\text { E. coli from } \\
\text { Industrial } \\
\text { Culture } \\
\text { Collection, China }\end{array}$ & $\begin{array}{l}\text { MIC } 80 \mu \mathrm{L} ; \mathrm{MBCs} \\
\text { AuNSps-0.02 and } \\
0.04 \mu \mathrm{g} ; \text { AuNCs-0.2 } \\
\quad \text { and } 0.4 \mu \mathrm{g}\end{array}$ & $\begin{array}{l}\text { Visible surface damage, disturbance } \\
\text { and cell loss by disruption of } \\
\text { membrane-bound components, loss of } \\
\text { flagella, loss of cell integrity, leakage of } \\
\text { cell contents into the environment, } \\
\text { death. }\end{array}$ & n.i. & {$[76]$} \\
\hline Ag-iNPs & \multirow{2}{*}{$\begin{array}{l}\text { Homogenized } \\
\text { microbial } \\
\text { solution of E. coli } \\
\text { commercial } \\
\text { lyophilized pellet } \\
\quad \text { (ATCC) }\end{array}$} & & \multirow{2}{*}{$\begin{array}{l}\text { Affected phospholipids, cytoplasm } \\
\text { proteins (GADPH). Created holes on } \\
\text { the outer membrane (OM), increased } \\
\text { the permeability of the membrane, led } \\
\text { to disruption of the breathing cycle } \\
\text { leading to its lysis; electrostatic } \\
\text { interaction, leading to disruption of the } \\
\text { integrity of the OM and activation of } \\
\text { OMPLA lipolytic enzymes; ROS } \\
\text { formation }\end{array}$} & $\begin{array}{l}\uparrow P l d A \\
\uparrow c u e O \\
\uparrow c o p A \\
\uparrow c u s R\end{array}$ & {$[77,78]$} \\
\hline $\mathrm{AgNO}_{3}$ & & & & $\begin{array}{l}\downarrow Z n t A \\
\text { gene } \\
\downarrow \text { CopA } \\
\text { gene } \\
\downarrow \text { CueO } \\
\text { gene }\end{array}$ & {$[77]$} \\
\hline $\mathrm{Cu} / \mathrm{SHfNP}$ & $\begin{array}{l}\text { E. coli SE4 } \\
\text { isolated from } \\
\text { hospital } \\
\text { wastewaters }\end{array}$ & $\begin{array}{l}\text { MIC } 2 \mathrm{mM}(98 \%) ; 1 \mathrm{mM} \\
\quad(91.9 \%) \text {-reduced } \\
\text { biofilm formation }\end{array}$ & $\begin{array}{l}\text { Loss of cellular components of cells; } \\
\text { reduced the level of attachment of } \\
\text { biofilm cells; disrupted nanowire } \\
\text { formation. }\end{array}$ & n.i. & [79] \\
\hline $\begin{array}{l}\text { BDCA-RNM (combination of } \\
\text { benzophenone tetracarboxylic } \\
\text { dianhydride and chlorogenic } \\
\text { acid membranes) }\end{array}$ & E. coli O157:H7 & $\mathrm{MBC} 10 \mu \mathrm{L}$ & $\begin{array}{l}\text { ROS production; cellular deformation } \\
\text { and surface collapse; lysed and } \\
\text { disrupted the bacterial cell walls and } \\
\text { membranes; leakage of nucleic acids } \\
\text { and proteins. }\end{array}$ & n.i. & {$[80]$} \\
\hline
\end{tabular}

$\uparrow$ Upregulated $\downarrow$ Downregulated.

The current progress in nanotechnology should allow the development of novel biocides to become the most exciting new field for researchers. Such novel developments include the gold-based biocide nanomaterials (nanospheres, nanostars, and nanocubes) [76] According to the latest studies, synthesized gold nanocubes (AuNCs) at low concentrations $(0.02$ and $0.04 \mu \mathrm{g}$ ) induce $100 \%$ inactivation against E. coli, P. aeruginosa, and S. aureus after only $30 \mathrm{~min}$ incubation [76]. The possible mechanisms of bacterial inactivation seem to be correlated with the physical mutilation of bacterial cells leading to cellular membrane damage and interaction with membrane-bound constituents. Similarly, silver-immobilized nanoparticles (Ag-iNPs) cause a bactericidal effect against $E$. coli [77] by upregulating the PldA gene encoding a membrane phospholipase $\mathrm{A}$, which is connected with the primary step of Ag-iNPs' bactericidal mechanism that eventually triggers the appearance of breaches in the outer membrane and stresses the cellular respiration processes. More detail on the biocides' mechanisms of action against $E$. coli is presented in Table 1.

\subsection{Pseudomonas spp.}

Pseudomonas aeruginosa, another member of the ESKAPE pathogen group, is well known for being able to cause serious infections due to its capacity to form highly resilient and tolerant biofilms and fight many antimicrobial agents [81]. As such it is a resistant and ubiquitous multidrug pathogen associated with many serious diseases, such as lung infections in cystic fibrosis patients and various septic syndromes [81,82]. Resistance in P. aeruginosa occurs due to the upregulation of efflux pumps, chromosomal $\beta$-lactamase, 
and mutations of antibiotic target molecules [82]. There is then no surprise that testing the efficiency of novel biocides is discussed in the scientific literature regarding their capacity to prevent biofilm formation of the most common species, including P. aeruginosa and P. fluorescens. For example, in order to combat Pseudomonas spp., surface contamination biocides such as the peracetic acid (PAA), sodium hypochlorite ( $\mathrm{SH}$ ), and chlorhexidine gluconate (CHDN) were tested against 185 Pseudomonas spp. isolates from a processing plant, with several of them demonstrating proteolytic and lipolytic activity [83]. After biofilm formation by P. fluorescens and P. aeruginosa on the stainless steel surfaces, these biocides were applied in different concentrations (SH at $100 \mathrm{mg} / 1$, PAA at $300 \mathrm{mg} / 1$, and CHDN at $400 \mathrm{mg} / \mathrm{lL}$ ), and the results showed a statistically significant reduction in $P$. aeruginosa biofilms. The authors concluded that all three studied biocidal agents did not completely eradicate biofilms from stainless steel surfaces.

The recently designed pyridoxine-based quaternary ammonium derivatives of terbinafine, containing the active compound KFU-127, were able to significantly inhibit (at $64 \mu \mathrm{g} / \mathrm{mL}$ concentration) the growth of $P$. aeruginosa and partly eradicate biofilm formation [11]. Unfortunately, although this biocide has shown exceptional results in the control of other pathogens, it was also mentioned by the authors to exhibit toxic effects on eukaryotic cells, so its application should be limited. On contrary, a new biocide synthesized from soybean oil and designed to control harmful aquatic microorganisms [84] (named LGPcide) showed strong bactericidal efficiency against $P$. fluorescens and other marine microorganisms. The authors concluded that after $24 \mathrm{~h}$, LGPcide reduced pathogen presence by $99.5 \%$ and showed a low toxicity compared to other maritime industrial biocides such as menadione, zinc sulfate, diuron, and irgarol. The bactericidal effect was suggested to depend on the biocide dosage but still involved the ability to alter the cell membranes, cell fluidity, and structure.

Glycolic acid (GA) and glyoxal (GO), in contrast to reference biocides benzalkonium chloride (BAC) and peracetic acid (PAA), were used to emphasize the importance of an efficient interaction with cell membranes, in a food spoilage model, by measuring their antimicrobial activity. Using this model, the biocides were shown to interact chemically with the cell surface of $P$. fluorescens (ATCC 13525), with the exception of GO which was actually shown to physiochemically interact with bacteria. Increased doses of all biocides (PAA, BAC, GA, and GO) affected the cell culturability, and the total eradication occurred at the elevated concentrations between 0.5 and $15 \mu \mathrm{g} / \mathrm{mL}$ that caused a $5 \log \mathrm{CFU} / \mathrm{mL}$ reduction. Glycolic acid (GA) raised the hydrophobicity and depleted the electron donor properties of $P$. fluorescens [85]. Conclusively, such biocides express their antimicrobial action by acting as a membrane-active and oxidant agent and inhibit bacterial replication. More detail on the biocides' mechanisms of action against Pseudomonas spp. is presented in Table 2.

Table 2. Biocides and their impact on Pseudomonas spp.

\begin{tabular}{|c|c|c|c|c|c|}
\hline Biocide & Strain & Concentration & Mechanism/Notes & Gene/Protein & Ref. \\
\hline $\begin{array}{l}\text { Cellulose foam } \\
\text { filter paper with } \\
\text { GA and BTCA }\end{array}$ & P. aeruginosa NCDC 105 & $\mathrm{MIC} 1 \mathrm{~g} / \mathrm{L}$ & $\begin{array}{l}\text { BTCA-crosslinking agent. Possible } \\
\text { mechanism-its acidic nature reduces } \\
\text { the pH of the medium, which inhibits } \\
\text { bacterial growth; } \\
\text { Glutaraldehyde-cross-binding of the } \\
\text { molecule with the amines of bacterial } \\
\text { cells, interfering in the transport and } \\
\text { enzymatic activities, which disrupts } \\
\text { the work of the main functions, } \\
\text { causing bactericidal effect. }\end{array}$ & n.i. & {$[13]$} \\
\hline $\begin{array}{l}\text { AuNSps } \\
\text { AuNSts } \\
\text { AuNCs }\end{array}$ & $\begin{array}{l}\text { P. aeruginosa obtained } \\
\text { from the China Center } \\
\text { for Industrial Culture } \\
\text { Collection }\end{array}$ & $\begin{array}{c}\text { MIC: } 80 \mu \mathrm{L} ; \text { MBCs: } \\
\text { AuNSps-0.02 and } 0.04 \mu \mathrm{g} ; \\
\text { AuNCs-0.2 and } 0.4 \mu \mathrm{g}\end{array}$ & $\begin{array}{l}\text { Surface damage, disturbance, cell loss } \\
\text { by disruption of membrane-bound } \\
\text { components, loss of flagella, leakage of } \\
\text { cell contents into the environment. }\end{array}$ & n.i. & {$[76]$} \\
\hline
\end{tabular}


Table 2. Cont.

\begin{tabular}{|c|c|c|c|c|c|}
\hline Biocide & Strain & Concentration & Mechanism/Notes & Gene/Protein & Ref. \\
\hline KFU-127 & $\begin{array}{c}\text { P. aeruginosa ATCC } \\
27853\end{array}$ & $\mathrm{MIC} / \mathrm{MBC} 64 \mu \mathrm{g} / \mathrm{mL}$ & $\begin{array}{l}\text { Cell membrane damage and changes; } \\
\text { inhibitory property on } \\
\text { pyroxidal-dependent enzymes. }\end{array}$ & n.i. & [11] \\
\hline $\begin{array}{c}\text { CHX-1\% } \\
\text { BKC-1\% } \\
\text { Kohrsolin extra } \\
\text { SEPTI-Turbo }\end{array}$ & $\begin{array}{l}\text { P. aeruginosa NCTC } \\
10662 \text { and } P \text {. aeruginosa } \\
\text { isolates collected from } \\
\text { different hospitals in } \\
\text { Hamadan city, Iran }\end{array}$ & $\begin{array}{l}\text { MICs: CHX-8-128 } \mu \mathrm{g} / \mathrm{mL} ; \\
\text { BKC-8-64 } \mu \mathrm{g} / \mathrm{mL} ; \\
\text { Kohrsolin } \\
\text { extra-8-32 } \mu \mathrm{g} / \mathrm{mL} ; \\
\text { SEPTI-Turbo-8-128 } \mu \mathrm{g} / \mathrm{mL}\end{array}$ & n.i. & $\begin{array}{l}\downarrow \text { cep } A \text { gene } \\
\downarrow \text { qacE } \Delta 1 \text { gene } \\
\downarrow \downarrow \text { qacE gene }\end{array}$ & [86] \\
\hline PHMG-Cl & $\begin{array}{c}\text { P. aeruginosa ATCC } \\
27853\end{array}$ & & $\begin{array}{l}\text { PHMG-Cl attaches high molecular } \\
\text { weight DNA and plasmid DNA, } \\
\text { resumes the process of inactivation of } \\
\text { DNA from surfaces. }\end{array}$ & $\downarrow e D N A$ gene & [87] \\
\hline $\begin{array}{l}\text { PAA } \\
\text { SH } \\
\text { CHDN }\end{array}$ & $\begin{array}{c}\text { P. aeruginosa and } P \text {. } \\
\text { fluorescens isolated from } \\
\text { a cheese processing line } \\
\text { at a dairy industry } \\
\text { located in Sao Paulo, } \\
\text { Brazil }\end{array}$ & $\begin{array}{l}\text { MBCs: PAA-300 mg/L; } \\
\text { SH-100 mg/L; } \\
\text { CHDN-400 mg/L }\end{array}$ & $\begin{array}{l}\text { PAA_-bactericidal action linked to } \\
\text { hypochlorous acid, crosses the cell } \\
\text { membrane, oxidizes the sulfhydryl } \\
\text { groups of certain enzymes; SH-strong } \\
\text { oxidizing agent of the cytoplasmic } \\
\text { membrane, deactivating physiological } \\
\text { functions; CHDN-reacts with the } \\
\text { negatively charged microbial cell } \\
\text { surface, destroying the cell membrane, } \\
\text { penetrates into the cell and causes } \\
\text { leakage of intracellular components. }\end{array}$ & n.i. & [83] \\
\hline LGPcide & $\begin{array}{l}\text { P. fluorescens isolated } \\
\text { from natural seawater } \\
\text { from Praia dos Anjos } \\
\text { Bay, Brazil }\end{array}$ & $\begin{array}{l}\text { MBC reduction }>99.5 \% \text { after } \\
24 \mathrm{~h}\end{array}$ & $\begin{array}{l}\text { High concentrations cause damage to } \\
\text { cell membranes; disturbance of } \\
\text { membrane structure and fluidity. }\end{array}$ & n.i. & [84] \\
\hline $\begin{array}{l}\text { GA } \\
\text { GO }\end{array}$ & P. fluorescens & $\begin{array}{c}\text { MBCs: GA-1000 } \mu \mathrm{g} / \mathrm{mL} ; \\
\text { GO-15000 } \mu \mathrm{g} / \mathrm{mL}\end{array}$ & $\begin{array}{l}\text { GA-active membrane and oxidizing } \\
\text { agent, reversible on the cell envelope if } \\
\text { applied in low concentrations; } \\
\text { GO_-effects absent on bacterial surface, } \\
\text { cell replication inhibitor (irreversible } \\
\text { effects). }\end{array}$ & n.i. & [85] \\
\hline ILs & $\begin{array}{c}\text { P. aeruginosa PAO1 and } \\
\text { PA14 }\end{array}$ & & $\begin{array}{l}\text { Permeabilization and disrupting the } \\
\text { bacterial OM; interact with the lipid } \\
\text { portion of the phospholipid, } \\
\text { destabilizing the bilayer by breaking } \\
\text { hydrophobic interaction between lipids } \\
\text { responsible for the integrity of the } \\
\text { membrane. }\end{array}$ & n.i. & {$[88]$} \\
\hline
\end{tabular}

$\uparrow$ Upregulated $\downarrow$ Downregulated.

\subsection{Klebsiella spp.}

Identified in the 1880s, this pathogen is considered opportunistic in humans, being responsible for causing urinary tract and hospital-based infections, acute liver abscesses, and pneumonia [89]. Other important members of the ESKAPE pathogen group [90], Klebsiella spp. are frequently isolated from water and soil and are reported as capable of forming biofilm and infecting a wide variety of plants and mammals (Table 3) [91]. Recent in vitro studies indicated that K. pneumoniae biofilm formation can be controlled by biocidic agents such as chlorhexidine digluconate (CHX), triclosan (TRI), and ethanol (ETH) [92]. These biocides were found responsible for a significant reduction in conjugation frequency of the OXA48 plasmids, responsible for carbapenemase production, especially in high-risk pathogenic clones. Similar to Pseudomonas spp., major attention is given to the efficacy of these biocides against Klebsiella spp. and to the possibility of resistance development. In a study from a Peruvian hospital, it was reported that K. pneumoniae strains pretreated with two hospital-used biocides recorded MICs from 8 to $128 \mu \mathrm{g} / \mathrm{mL}$ for chlorhexidine and variations from 16 to $256 \mathrm{mg} / \mathrm{mL}$ for isopropanol, highlighting an increased resistance pattern [93]. However, the biocidal activity was impacted by the temperature and growth medium, suggesting that these variables could significantly affect the biological activity of many types of studied biocides. 
New biocidal products such as metal ion solutions (e.g., copper, gold, palladium, platinum, and silver) might also impact the growth and biofilm formation of K. pneumoniae [94]. A recent study has reported an effective antimicrobial metal ion solution against K. pneumoniae (NCTC9633), which was achieved by platinum with an MIC of $3.90 \mathrm{mg} / \mathrm{L}$. A higher bactericidal effect was reported after pretreating bacteria with palladium, platinum, and gold at $3.90 \mathrm{mg} / \mathrm{L}$ [94]. They are also reported as having a synergistic action where elevated concentrations of metal ions resulted in total inhibition of K. pneumoniae biofilm formation (at $500 \mathrm{mg} / \mathrm{L}$ ) by combining gold with palladium, gold with platinum, platinum with palladium, silver with palladium, or copper with gold. To prevent water contamination, it has been described that cellulose filter paper pretreated with cationic polyacrylamide and infused with glutaraldehyde solution or 1,2,3,4-butane tetracarboxylic acid (BTCA) inhibited K. pneumoniae (NCDC 138) growth in drinking water [13]. Metal-based nanoparticles were described as highly efficient in combating bacterial contamination in drinking water. Calcium hypochlorite $\left(\mathrm{Ca}(\mathrm{OCl})_{2}\right)$, silver nanoparticles $(\mathrm{AgNPs})$, and $\mathrm{Ca}(\mathrm{OCl})_{2} / \mathrm{AgNPs}$ composites showed efficient biocidal properties against $K$. pneumoniae and other pathogens isolated from tap and hand pump waters. Results have shown that AgNPs loaded with $\mathrm{Ca}(\mathrm{OCl})_{2}$ had lethal effects at the concentration of $1.5 \mathrm{mg} / \mathrm{L}$ against K. pneumoniae, E. coli, and S. aureus after only $180 \mathrm{~min}$ of exposure [95]. Conclusively, the development of impregnated filters with such metal-based nanoparticles could induce absolute biocidal effects against water-based pathogens.

Table 3. Biocides and their impact on Klebsiella spp.

\begin{tabular}{|c|c|c|c|c|c|}
\hline Biocide & Strain & Concentration & Mechanism/Notes & Gene/Protein & Ref. \\
\hline $\begin{array}{l}\text { Chlorhexidine } \\
\text { Octenidine }\end{array}$ & K. pneumoniae MGH 78578 & $\begin{array}{c}\text { MICs: } 8 \mathrm{mg} / \mathrm{L} \text { and } \\
1 \mathrm{mg} / \mathrm{L} ; \mathrm{MBCs}: \\
128 \mathrm{mg} / \mathrm{L} \text { and } 16 \mathrm{mg} / \mathrm{L}\end{array}$ & n.i. & $\begin{array}{l}\uparrow s m v A \\
\uparrow s m v R\end{array}$ & [96] \\
\hline $\begin{array}{l}\text { Chlorhexidine } \\
\text { Isopropanol }\end{array}$ & $\begin{array}{c}\text { Klebsiella spp. from } \\
\text { collections of the } \\
\text { Universidad Cientifica de } \\
\text { Sur in Lima, Peru. K. } \\
\text { pneumoniae from HN2M, } \\
\text { INMP, and HNGAI, Lima, } \\
\text { Peru }\end{array}$ & $\begin{array}{l}\text { MICs: } 32 \mu \mathrm{g} / \mathrm{mL}\left(\mathrm{MIC}_{50}\right) \\
\text { and } 64 \mu \mathrm{g} / \mathrm{mL}\left(\mathrm{MIC}_{90}\right)\end{array}$ & n.i. & & [93] \\
\hline $\begin{array}{l}\text { Derdevice plus } Y \\
\text { I\&D Sept }\end{array}$ & $\begin{array}{l}\text { K. pneumoniae CRKP } \\
\text { isolates obtained from Gazi } \\
\text { University, collection of the } \\
\text { Microbiology Laboratory }\end{array}$ & $\begin{array}{c}\text { MBC } 1 / 300 \text { dilution and } \\
100 \%\end{array}$ & n.i. & & [97] \\
\hline $\mathrm{Au}, \mathrm{Cu}, \mathrm{Pt}, \mathrm{Pd}, \mathrm{Ag}$ & K. pneumoniae NCTC9633 & $\begin{array}{c}\text { MICs: } \mathrm{Au}-5.85 \mathrm{mg} / \mathrm{L} ; \\
\mathrm{Cu}-15.62 \mathrm{mg} / \mathrm{L} ; \\
\mathrm{Pt}-3.90 \mathrm{mg} / \mathrm{L} ; \\
\mathrm{Pd}-5.85 \mathrm{mg} / \mathrm{L} ; \\
\mathrm{Ag}-11.71 \mathrm{mg} / \mathrm{L} ; \mathrm{MBCs} \\
\mathrm{Au}-3.90 \mathrm{mg} / \mathrm{L} ; \\
\mathrm{Cu}-15.62 \mathrm{mg} / \mathrm{L} ; \\
\mathrm{Pt}-3.90 \mathrm{mg} / \mathrm{L} ; \\
\mathrm{Au}-3.90 \mathrm{mg} / \mathrm{L} ; \\
\mathrm{Pd}-3.90 \mathrm{mg} / \mathrm{L}\end{array}$ & $\begin{array}{l}\text { Toxic effects of metals can cause } \\
\text { DNA damage, antioxidant } \\
\text { depletion, disturbance of } \\
\text { membrane function, structural } \\
\text { changes in the cell wall, increased } \\
\text { cell permeability, lysis of the cell. }\end{array}$ & n.i. & [94] \\
\hline $\begin{array}{l}\text { Cellulose foam paper } \\
\text { with GA and BTCA }\end{array}$ & K. pneumoniae NCDC 138 & MIC $1-2 \mathrm{~g} / \mathrm{L}$ & $\begin{array}{l}\text { BTCA-crosslinking agent, } \\
\text { reduces pH of the medium and } \\
\text { inhibits bacterial growth; } \\
\text { GA-cross-binding of the } \\
\text { molecule with OM of bacterial } \\
\text { cells interferes in the enzymatic } \\
\text { activities and transport of the } \\
\text { bacterial cell. }\end{array}$ & n.i. & {$[13]$} \\
\hline $\begin{array}{l}\text { Filter paper with } \\
\mathrm{Ca}(\mathrm{OCl})_{2} / \mathrm{AgNPs}\end{array}$ & $\begin{array}{l}\text { K. pneumoniae isolated from } \\
\text { different water supplies }\end{array}$ & $\begin{array}{l}\text { MBC } 2.0 \mathrm{mg} / \mathrm{L}(70 \%) \\
1.0 \mathrm{mg} / \mathrm{L}(50 \%)\end{array}$ & $\begin{array}{l}\mathrm{Ag}^{+} \text {ions can bind and penetrate } \\
\text { the cell membrane, increasing } \\
\text { permeability. }\end{array}$ & n.i. & [95] \\
\hline
\end{tabular}

$\uparrow$ Upregulated. 


\subsection{Staphylococcus spp.}

Staphylococcus is one of the significant pathogens to be controlled in the meat industry and health establishments, particularly for its affinity to adhere the different surfaces [22] Members of the genus Staphylococcus can colonize the skin and airways of animals and birds, while highly pathogenic strains are associated with the events of minor, severe, or fulminant infections. To date, through unpredictable evolutionary processes, some of Staphylococcus species being ordinary constituents of human/animal microbiota have shifted towards evolving in pathogen-progressive strains [22].

Biocide resistance is a major issue in S. aureus, and preventing such resistance is a significant challenge for scientists. Human-associated S. aureus strains were reported to harbor a specific bacteriophage $\Phi S a 3$ which encrypts tricky evasive immune factors, but more recently, this prophage has also been detected in livestock-distributed S. aureus (MRSA) CC398 and evolved as a facilitator of human colonization [98]. In earlier studies, the ancestor of S. aureus (CC398) was reported as a strain adapted to humans, but due to the extensive human-livestock activities, it was transferred to animals via the loss of prophage Sa3 [99]. Commercial biocides based on hydrogen peroxide were recently described as capable of inducing the phage $\Phi 13$ from the Sa3 group that encodes human immune evasion genes associated with human colonization [98]. Furthermore, in vitro results showed that sublethal concentrations of hydrogen peroxide or biocides based on hydrogen peroxide were responsible for the transfer of prophage $\Phi 13$ from human S. aureus donor strain to livestock-associated MRSA CC398 61599 recipient strain. Clinically relevant isolates (MRSA and MSSA) can encode biocide resistance genes such as qacA/B and qacC [100]. An illustration of biocide resistance was described in S. aureus strains isolated from clinical samples from Egypt and showed that the presence of qacA/B genes caused increased MICs of sodium hypochlorite, phenol, and Savlon (chlorhexidine digluconate $0.3 \%$ and cetrimide 3\%). Likewise, the isolates of MRSA sampled from infected and healthy humans and animals from Germany recently displayed the presence of biocide and heavy metal tolerance-mediating factors such as cop $\mathrm{A}, c z r \mathrm{C}, \operatorname{lmrS}, m c o, \operatorname{mep} \mathrm{A}$, nor $\mathrm{A}, q a c \mathrm{~A}, q a c \mathrm{G}, q a c \mathrm{~J}$, sep A, and smr. Moreover, some of the important human lineages (e.g., CC22 and CC5) illustrated statistically significantly greater MICs for acriflavine, benzethonium chloride, and chlorhexidine compared with the origin of animal sequence type 398 (ST398) [101].

Most biofilm studies concentrate on the mechanistic aspects of biocide resistance. The promising biocidal nanoparticles [102] based on thymol-loaded chitosan silver nanoparticles (TCAgNPs) versus the biofilm formation and virulence-associated proteins of S. aureus (BapMRSA 090) had the capacity to reduce biofilm formation in a dose-dependent manner, with the most promising activity seen at the concentration of $200 \mu \mathrm{g} / \mathrm{mL}$ causing a significant $73.37 \%$ reduction compared to controls. Moreover, the higher concentrations $(500 \mu \mathrm{g} / \mathrm{mL})$ of TCAgNPs after $48 \mathrm{~h}$ exposure to $S$. aureus repressed the expression of Coa, Eap, and SpA exoprotein genes in contrast to the housekeeping control gene. It can be concluded that such approaches based on nanoparticles can specifically trigger and deactivate biofilm formation and impair the cell membrane of immune-evasive MRSA strains at MICs of only $1 \mathrm{mg} / \mathrm{mL}$ [103]. An innovative approach reported that iron oxide nanoparticles transported within the matrix through a magnetic field against MRSA can result in biofilm inactivation [104]. After the MRSA biofilm generation, the treatment with $5 \mathrm{mg} / \mathrm{mL}$ of magnetic nanoparticles (e.g., spheres, cubes, and tetrapods) in a rotating magnetic field condition induced significant differences and was achieved by cubic and tetrapod nanoparticles that displayed a $14.19 \log 10 \mathrm{CFU} /$ plate eradication, while spheric nanoparticles displayed only a $7.3 \pm 0.2 \log 10$ decrease. Given the large amount of data currently present in the literature, we have summarized the main results in Table 4. 
Table 4. Biocides and their impact on Staphylococcus spp.

\begin{tabular}{|c|c|c|c|c|c|}
\hline Biocide & Strain & Concentration & Mechanism/Notes & Gene/Protein & Ref. \\
\hline $\begin{array}{c}\text { Benzalkonium } \\
\text { chloride, } \mathrm{H}_{2} \mathrm{O}_{2} \\
\text { Biocide } 1, \text { Biocide } \\
\text { 2, Biocide 3, } \\
\text { mitomycin C }\end{array}$ & $\begin{array}{c}\text { S. aureus 8325-4 and } \\
\text { phages } 8325-4 \Phi 13 \text { (CG1); } \\
\text { RN420 8325-4Ф13-kana; } \\
\text { MW2- } \Phi S a 3 m w ; \text { MW2c; } \\
\text { 61599; 93616; DC10B; } \\
\text { 8325-4Ф13attBmut; } \\
\text { RN4220 } 13 \text { attBmut }\end{array}$ & $\begin{array}{c}\text { MICs: BC-2.67 } \mu \mathrm{g} / \mathrm{mL} ; \\
\mathrm{H}_{2} \mathrm{O}_{2}-0.03 \% \text { w } / \mathrm{w} ; \text { Biocide } \\
1-0.02 \% ; \text { Biocide } 2-0.02 \% \\
\text { Biocide } 3-5.00 \% \text {; mitomycin } \\
\text { C-0.12 mg/L }\end{array}$ & $\begin{array}{c}\text { Known as } h l b \text {-converting } \\
\text { phages which integrate in the } \\
h l b \text { gene at the } a t t \mathrm{~B} \text { attachment } \\
\text { site. }\end{array}$ & n.i. & [98] \\
\hline Chlorhexidine & $\begin{array}{l}\text { S. aureus isolates ST36 } \\
\left(q a c A^{+} \text {and } q a c A^{-}\right) ; \mathrm{ST} 22 \\
\left(q a c A^{+} \text {and } q a c A^{-}\right) ; \\
\text {ST239-TW }\left(q a c A^{+}\right)\end{array}$ & $\begin{array}{c}\text { ST22 clones-decrease } 45 \% \\
(1.47 \mathrm{mg} / \mathrm{L}) ; \mathrm{ST} 36 \text { clones-1.75 } \\
\mathrm{mg} / \mathrm{L}\end{array}$ & $\begin{array}{l}\text { Increased binding to } \\
\text { fibrinogen and fibronectin, } \\
\text { increased adhesion and } \\
\text { internalization into } \\
\text { monolayers of keratinocytes, } \\
\text { and confirms phenomenon of } \\
\text { survival in vivo after } \\
\text { chlorhexidine exposure. }\end{array}$ & n.i. & {$[105]$} \\
\hline $\begin{array}{l}\text { Hypochlorite and } \\
\text { Phenol }\end{array}$ & $\begin{array}{l}\text { MRSA and MSSA S. } \\
\text { aureus clinical isolates, } \\
\text { Egypt }\end{array}$ & $\begin{array}{l}\text { Association between the } \\
\text { presence of antiseptic } \\
\text { resistance genes and the MICs }\end{array}$ & n.i. & $\begin{array}{l}\uparrow q a c A / B, q a c C \\
\text { genes }\end{array}$ & {$[100]$} \\
\hline Chlorhexidine & $\begin{array}{l}201 \text { MRSA isolates from } \\
\text { Portuguese hospitals, } \\
\text { strain collection at } \\
\text { ITQB-NOVA in Oeiras, } \\
\text { Portugal }\end{array}$ & $\begin{array}{l}\text { MICs } 0.125-4 \mathrm{mg} / \mathrm{L} \text {, one of } \\
\text { them presented MICs } 0.5-1 \\
\mathrm{mg} / \mathrm{L} \\
\text { MBCs } 0.125-8 \mathrm{mg} / \mathrm{L}\end{array}$ & n.i. & $\begin{array}{l}\text { sep } A \text { and mepA } \\
(100 \%) ; \operatorname{lmrS} \\
(87.1 \%) ; \text { qacAB } \\
(22.4 \%) ; \text { smr } \\
(1.0 \%)\end{array}$ & {$[106]$} \\
\hline $\begin{array}{l}\text { F10SC } \\
\text { Hexacon }\end{array}$ & $\begin{array}{c}\text { S. pseudintermedius } \\
\text { (MRSP, MSSP) and S. } \\
\text { aureus (MRSA) clinical } \\
\text { isolates, Sydney, } \\
\text { Australia }\end{array}$ & $\begin{array}{c}\text { MBCs: F10SC-1.05-16.87 } \\
\text { mg/L; Hexacon-7.81-31.25 } \\
\text { mg/L }\end{array}$ & n.i. & $\begin{array}{c}\text { qac } A / B \\
\text { genes-were only } \\
\text { in MRSA isolates. } \\
\text { qacJ }(54 \%), \text { qacG } \\
(29 \%), s m r(7 \%) \\
\text { MRSP isolates. }\end{array}$ & {$[107]$} \\
\hline $\mathrm{Cu} / \mathrm{SHfNP}$ & S. aureus ATCC 6538 & $\begin{array}{l}\text { Reduced cell growth at the } \\
\text { highest concentration }(1 \mathrm{mM}) \\
\text { by } 86 \%\end{array}$ & $\begin{array}{l}\text { Damage cell membrane, } \\
\text { increase membrane's } \\
\text { permeability, disrupt cell } \\
\text { membrane at high dose ( } 2 \\
\text { mM). }\end{array}$ & n.i. & [79] \\
\hline Dex-MA & $\begin{array}{l}\text { S. aureus (MRSA) (ATCC } \\
\text { 33591) }\end{array}$ & $\begin{array}{l}\text { MICs: } 1-2 \mu \mathrm{g} / \mathrm{mL} ; \mathrm{MBCs} \\
\text { Dex-5-1.0 mg, Dex-10-1.9 } \\
\text { mg, Dex-20-4.1 mg }\end{array}$ & n.i. & n.i. & {$[108]$} \\
\hline $\begin{array}{l}\text { PAA } \\
\text { Chlorhexidine } \\
\text { digluconate }\end{array}$ & $\begin{array}{l}\text { S. aureus BZ012 and Sa30 } \\
\text { from Brazilian dairies }\end{array}$ & $\begin{array}{l}\text { MICs: PAA- }-0.075 \% \text { ( } 4.6 \log ) \\
\text { and } 0.015 \%(1.1 \log ) \text { mixed } \\
\text { cultures; chlorhexidine } \\
\text { dicluconate-0.0001953125 } \\
\text { and } 0.025 \% \text { mixed cultures. }\end{array}$ & n.i. & n.i. & [109] \\
\hline T-C@AgNPs & S. aureus (Bap-MRSA) & n.i. & $\begin{array}{l}\text { Damage and destabilization of } \\
\text { membrane of bacterial cell. } \\
\text { Bioelectrical changes caused } \\
\text { by biocide (intramembrane } \\
\text { space to outside the cell) create } \\
\text { pores-dose-dependent. }\end{array}$ & $\begin{array}{l}\downarrow \text { Coa }, \downarrow \text { Eap }, \downarrow S p A, \\
\quad \downarrow \text { Bap genes }\end{array}$ & {$[102]$} \\
\hline GTAgNPs & S. aureus 090 (MRSA090) & $\mathrm{MIC} 20 \mathrm{mg} / \mathrm{mL}$ & $\begin{array}{l}\text { Presents antioxidant } \\
\text { dose-dependent activity. } \\
\text { Neutralizing ROS. }\end{array}$ & $\begin{array}{l}\downarrow C o a, \downarrow \text { Eap }, \downarrow S p A \\
\text { genes }\end{array}$ & [103] \\
\hline $\begin{array}{l}\text { PVDF/GN and } \\
\text { PVDF/SP }\end{array}$ & S. aureus ATCC 25923 & Caused a $6-\log$ reduction & $\begin{array}{l}\text { Bactericidal action confirmed } \\
\text { with the presence of } \\
\text { intracellular ROS. }\end{array}$ & n.i. & {$[12]$} \\
\hline $\begin{array}{l}\text { MBQ (magnetic } \\
\text { biochar/quaternary } \\
\text { phosphonium } \\
\text { salt) }\end{array}$ & S. aureus ATCC 6538 & $\begin{array}{l}\text { MBC: } 2 \mathrm{mg} / \mathrm{L}(50 \%), 50 \mathrm{mg} / \mathrm{L} \\
(90 \%) \text {, dose-dependent effects }\end{array}$ & $\begin{array}{l}\text { Loss of cell integrity, the } \\
\text { appearance of vacuolization, } \\
\text { rupture of cell surface and } \\
\text { leakage of intracellular } \\
\text { substances, Induced oxidative } \\
\text { stress, penetrates through the } \\
\text { lipid bilayers, and increases } \\
\text { membrane structural } \\
\text { destabilization. }\end{array}$ & n.i. & {$[73]$} \\
\hline
\end{tabular}


Table 4. Cont.

\begin{tabular}{|c|c|c|c|c|c|}
\hline Biocide & Strain & Concentration & Mechanism/Notes & Gene/Protein & Ref. \\
\hline $\begin{array}{l}\text { AuNSps } \\
\text { AuNSts } \\
\text { AuNCs }\end{array}$ & $\begin{array}{l}\text { S. aureus from CICC, } \\
\text { Beijing China }\end{array}$ & MICs $0.04 \mu \mathrm{g}$ & $\begin{array}{l}\text { Surface damage, disturbance, } \\
\text { and cell loss by disruption of } \\
\text { membrane-bound components, } \\
\text { loss of flagella, cell integrity, } \\
\text { leakage of cell contents into } \\
\text { environment. }\end{array}$ & n.i. & {$[76]$} \\
\hline СТАВ & S. aureus (MRSA) & $\begin{array}{l}\text { Cubic and tetrapod } \\
\text { nanoparticles-14.19 } \log _{10} \\
\text { CFU/plate eradication; spheric } \\
\text { nanoparticles-7.3 } \pm 0.2 \log _{10} \\
\text { decrease }\end{array}$ & n.i. & n.i. & [104] \\
\hline KFU-127 & $\begin{array}{c}\text { S. aureus ATCC 29213, S. } \\
\text { epidermidis clinical isolate } \\
\text { from Kazan Institute, } \\
\text { Russia }\end{array}$ & $\begin{array}{c}\text { MICs: } 4 \mu \mathrm{g} / \mathrm{mL} ; \text { MBCs: } 8 \\
\mu \mathrm{g} / \mathrm{mL}\end{array}$ & $\begin{array}{l}\text { Membrane potential changes } \\
\text { and cell membrane damage; } \\
\text { inhibitory property on } \\
\text { pyroxidal-dependent enzymes. }\end{array}$ & n.i. & {$[11]$} \\
\hline
\end{tabular}

$\uparrow$ Upregulated $\downarrow$ Downregulated.

\subsection{Listeria spp.}

Listeria spp. are rod-shaped, Gram-positive bacteria commonly found in assorted food products and on industrial surfaces; they are notorious for causing life-threatening infections known as listeriosis and septicemia [22,110]. Several outbreaks were associated with the consumption of contaminated dairy and ready-to-eat (RTE) products, including fruit and vegetables [111]. Biocide tolerance in L. monocytogenes strains (Table 5) shares similar mechanisms to antibiotic tolerance [112]. However, some authors did not identify biocide and antibiotic crossresistance in their in vitro adaptation experiments when bacteria were exposed to sublethal concentrations of disinfectants. [113]. However, others indicated that strains isolated from diverse ecological niches exposed to quaternary ammonium compounds (QACs) coselected antibiotic resistance. According to the same authors, Listeria spp. have the ability to adapt to biocides, especially QACs, and adaptation is linked to coresistance to ciprofloxacin [114].

Table 5. Biocides and their impact on Listeria spp.

\begin{tabular}{|c|c|c|c|c|c|}
\hline Biocide & Strain & Concentration & Mechanism/Notes & Gene/Protein & Ref. \\
\hline \multirow{3}{*}{$\begin{array}{l}\text { Benzalkonium } \\
\text { chloride }\end{array}$} & L. monocytogenes SLCC2540 & $\begin{array}{c}\mathrm{MIC} 4 \mu \mathrm{g} / \mathrm{mL} ; \mathrm{MBC} \\
11 \mu \mathrm{g} / \mathrm{mL}\end{array}$ & $\begin{array}{c}\text { Increased abundance } \\
\text { of viable but } \\
\text { nonculturable cells. }\end{array}$ & $\begin{array}{l}\text { May induce mutations in } \\
\text { efflux pump systems, which } \\
\text { are responsible for multidrug } \\
\text { resistance }\end{array}$ & [115] \\
\hline & L. monocytogenes ST6 & $\begin{array}{l}\text { Greater than } \\
10 \mu \mathrm{g} / \mathrm{mL}\end{array}$ & n.i. & $\begin{array}{l}\text { BC tolerance due to the } \\
\text { presence of pLMST6 plasmid } \\
\text { (EmrC gene responsible for } \\
\text { the multidrug efflux pump } \\
\text { protein) }\end{array}$ & [116] \\
\hline & $\begin{array}{l}\text { L. monocytogenes isolated from } \\
\text { South Africa food chain } \\
\text { (e.g., ST1, ST2, ST121, ST204, } \\
\text { and ST321) }\end{array}$ & n.i. & n.i. & $\begin{array}{c}\uparrow b c r A B C \text { cassette } \\
\uparrow e r m C \\
\uparrow m d r L \\
\uparrow I d e \\
\uparrow S S I-1 \\
\uparrow \text { SSI-2 }\end{array}$ & [117] \\
\hline ВР1-ВР5ВР6-ВР11 & $\begin{array}{c}\text { L. monocytogenes isolated } \\
\text { strains } 2075,2081 \text {, and } 2355 \\
\text { from the mushroom } \\
\text { production environment. } \\
\text { Strains } 3050,3051,3101,3102, \\
\text { and } 3104 \text { isolated from the } \\
\text { production environment after } \\
\text { steam cookout }\end{array}$ & $\begin{array}{c}\text { 1.7-log and 6-log } \\
\text { reductions; } \\
\text { the highest reduction, } \\
\text { 6- } \log -\mathrm{BP} 6 \text { and BP11 } \\
\text { MICs ranged } \\
\text { between } 1 \text { and } 50 \%\end{array}$ & n.i. & n.i. & [118] \\
\hline Triclosan & L. monocytogenesL. welshimeri & $\begin{array}{l}\text { MIC from } 0.0015 \text { to } \\
0.006 \%\end{array}$ & n.i. & n.i. & [119] \\
\hline
\end{tabular}


Table 5. Cont.

\begin{tabular}{|c|c|c|c|c|c|}
\hline Biocide & Strain & Concentration & Mechanism/Notes & Gene/Protein & Ref. \\
\hline Cadmium chloride & $\begin{array}{l}\text { L. monocytogenes isolates from } \\
\text { food-processing } \\
\text { environments, Brazil }\end{array}$ & $\begin{array}{l}\text { Ranged from } 20 \text { to } \\
200 \mu \mathrm{g} \cdot \mathrm{mL}^{-1}\end{array}$ & n.i. & $\begin{array}{l}\text { Presence of the efflux pumps } \\
\text { MdrL and Lde, cadmium } \\
\text { chloride resistance }\end{array}$ & {$[120]$} \\
\hline $\begin{array}{c}\text { PAA } \\
\text { Chlorhexidine }\end{array}$ & $\begin{array}{l}\text { Listeria monocytogenes BZ001 } \\
\text { isolated from a single } \\
\text { food-processing environment }\end{array}$ & $\begin{array}{l}\text { MIC } 0.075 \% \text { for PAA } \\
\text { and } 0.000390625 \% \text { for } \\
\text { chlorhexidine }\end{array}$ & n.i. & n.i. & [109] \\
\hline
\end{tabular}

$\uparrow$ Upregulated.

Inappropriate use of disinfectants could result in acquired resistance, and it was previously illustrated that L. monocytogenes could become resistant to biocides (benzalkonium chloride) and cause improved biofilm formation in BZK-resistant strains by involving various resistance mechanisms and genetic mechanisms (Table 5) [121]. Listeria strains from Brazilian tilapiaprocessing facilities are examples of such resistant strains as they had significantly increased ability to form biofilm on polystyrene and stainless steel surfaces [122]. Higher concentrations of sodium hypochlorite and peracetic acid were required for complete eradication, indicating an increased resistance. The biofilm formed on polystyrene by L. monocytogenes isolates, from pork meat, was significantly reduced when pretreated for $10 \mathrm{~min}$ with sodium hypochlorite (MICs ranging from 1 to 1.5) and benzalkonium chloride ((MICs ranging from 0.5 to 1.5) [123]. The maximum reduction of $90 \%$ was reported for sodium hypochlorite. In conclusion, none of the biocides were able to induce a complete eradication of biofilm. The decreased eradication capacity of benzalkonium chloride is caused by the presence of resistance determinants bearing bcrABC and qacH genes [124,125]. A similar pattern was described for L. monocytogenes isolates from food-processing environments in southern Brazil harboring the efflux pumps MdrL and Lde and resistance to cadmium chloride [120]. Separate review papers are necessary to link the ability of a microorganism to multiply with its resistance capacity as resistance might provide certain pathogens with the necessary ability to inhibit the growth of other bacteria for their own benefit.

\subsection{Campylobacter spp.}

Campylobacter spp. are a spiral-shaped, Gram-negative, microaerophilic bacteria being especially more prevalent in poultry than in ubiquitous environments [20]. These bacteria have a unique fast transmissibility and colonization rate in animals and humans, predominantly via consumption of contaminated water, food, eggs, milk, and undercooked meat. On a global scale, Campylobacter is the major cause of gastroenteritis and is one of the most widespread causative pathogens of infectious diseases of the last century [126]. As such, controlling the spread of this pathogen is vital, not only in food processing facilities, but also in hospital or poultry farming environments and solutions are provided in Table 6. A recent article indicated that $99 \%$ of poultry-isolated C. jejuni strains had highly increased resistance to triclosan, $32 \%$ of strains showed resistance to chlorhexidine, and all of the strains were susceptible to benzalkonium chloride [127]. The most effective antimicrobial substance was didecyldimethylammonium chloride, which also acted in a synergetic way with benzyldimethyldodecylammonium chloride and inhibited C. jejuni [128].

Table 6. Biocides and their impact on Campylobacter spp.

\begin{tabular}{|c|c|c|c|c|c|}
\hline Biocide & Strain & Concentration & Mechanism/Notes & Gene/Protein & Ref. \\
\hline $\begin{array}{c}\text { Triclosan } \\
\text { Chlorhexidine } \\
\text { Benzalkonium chloride }\end{array}$ & $\begin{array}{c}96 \text { C. jejuni strains } \\
\text { isolated from poultry } \\
\text { industry }\end{array}$ & $\begin{array}{c}\text { MIC50 = } 32 \text { and } \\
\text { MIC } 90=32(\mu \mathrm{g} / \mathrm{mL}) \\
\text { MIC50 = } 0.5 \text { and } \\
\text { MIC90 = 1; } \\
\text { MIC50 = } 1 \text { and MIC } 90=2\end{array}$ & n.i. & $\begin{array}{l}99 \% \text { of strains showed } \\
\text { triclosan resistance; } 32 \% \\
\text { chlorhexidine resistance; } \\
100 \% \text { susceptible to } \\
\text { benzalkonium chloride }\end{array}$ & [127] \\
\hline Chlorine & $\begin{array}{c}\text { C. jejuni from poultry } \\
\text { carcasses }\end{array}$ & $\begin{array}{l}\text { MIC: } 8 \text { ppm for } 97.5 \% \\
\text { MBC: } 128 \text { ppm }\end{array}$ & $\begin{array}{l}\text { Dose-dependent } \\
\text { mechanisms, can be } \\
\text { resuscitated after } \\
\text { chlorine treatment. }\end{array}$ & n.i. & [129] \\
\hline
\end{tabular}


Table 6. Cont.

\begin{tabular}{|c|c|c|c|c|c|}
\hline Biocide & Strain & Concentration & Mechanism/Notes & Gene/Protein & Ref. \\
\hline $\begin{array}{l}\text { Antimicrobial mixtures } \\
\text { based on sodium } \\
\text { chloride, sodium } \\
\text { hydroxide, citrus, } \\
\text { oregano, and grape seed } \\
\text { extracts }\end{array}$ & $\begin{array}{l}\text { C. coli isolates (NC1, } \\
\text { NC2, and NC3) and } \\
\text { cecum strain (RC018) }\end{array}$ & MIC: $0.25-1 \%$ & n.i. & $\downarrow$ inhibit T6SS (hcp) & {$[20]$} \\
\hline PinA & $\begin{array}{c}\text { C. jejuni }(81-176 \text { and } \\
\text { F38011) }\end{array}$ & MIC: $256 \mu \mathrm{g} / \mathrm{mL}$ & $\begin{array}{c}\text { Membrane } \\
\text { disruption, pore } \\
\text { formation, increases } \\
\text { membrane } \\
\text { permeability. }\end{array}$ & n.i. & [130] \\
\hline $\begin{array}{l}\text { Disinfectant based on } \\
\text { glutaraldehyde, } \\
\text { formaldehyde, and } \\
\text { antifreeze }\end{array}$ & $\begin{array}{l}\text { C. fetus subsp. } \\
\text { venerealis and } C \text {. } \\
\text { fetus subsp. Fetus }\end{array}$ & MIC: $0.5 \%$ & n.i. & n.i. & [131] \\
\hline
\end{tabular}

Campylobacter is indeed a serious and persistent issue for the poultry industry and identification of efficient biocides is still a struggle [132]. Chlorine, one example, is widely used as a standard biocide in the poultry industry (Table 6) to decrease bacterial loads in poultry carcasses and skins. Recent in vitro research showed that chlorine might effectively decrease $C$. jejuni in poultry carcasses before washing, but notably without completely eradicating the pathogen [129]. The complete pathogen inhibition occurred at chlorine MICs above $8 \mathrm{ppm}$. However, due to genetic variations of the species and different involved tolerance mechanisms, chlorine sensitivity can vary in Campylobacter. In some cases, at high bacterial growth concentrations, Campylobacter spp. were resuscitated after chlorine treatment, suggesting an update of chlorine usage or new possible alternatives. More promising effects were achieved in another in one of our studies in which an antimicrobial mixture based on sodium chloride, sodium hydroxide, citrus, oregano, and grape seed extracts reduced pathogen presence on poultry neck skins and whole carcasses [20]. On the other hand, in healthcare facilities, puroindoline A (PinA) could act as a therapeutic biocide or as a preservative agent in the agri-food industry [130]. In vitro analysis has reported that PinA peptides inhibited C. jejuni (81-176 and F38011) biofilm formation at $256 \mu \mathrm{g} / \mathrm{mL}$ concentration. Treatment of $C$. jejuni isolates with PinA disrupted and modified the cell membrane and made it prone to permeability to other external substances. The PinA mechanism of membrane disruption via the formation of pores in the lipid bilayers was interlinked with the existence of disulfide bonds and hydrophobic tryptophan-rich domains (TRDs) in its chemical structure.

\subsection{Salmonella spp.}

The clinical manifestations of Salmonella infections are similar with those of Campylobacter infections, with both requiring the use of antibiotics and proton pump inhibitors to reduce symptom severity [22]. According to the latest data, salmonellosis is the second most documented gastrointestinal human infection in Europe after campylobacteriosis [133]. Furthermore, Salmonella can form robust biofilms on various abiotic and biotic surfaces, which confers tolerance to several stresses and antimicrobials, including biocides [134]. Biocides aiming to be efficient in eradicating Salmonella in food processing environments will have to overcome the increased expression of efflux pump genes and its high capacity for biofilm formation. It was suggested that biofilm-forming bacteria must also be considered for complete and efficient sanitation of food-contact surfaces besides the planktonic cell targeting [135]. The biological mechanisms involved in the eradication of Salmonella spp. by biocides are as complex as those for the other microorganisms discussed in this review (Table 7). 
Table 7. Biocides and their impact on Salmonella spp.

\begin{tabular}{|c|c|c|c|c|c|}
\hline Biocide & Strain & Concentration & Mechanism/Notes & Gene/Protein & Refs. \\
\hline $\begin{array}{c}\text { Chlorine } \\
\text { QACs }\end{array}$ & $\begin{array}{l}\text { S. enterica isolated } \\
\text { from processing } \\
\text { environments }\end{array}$ & $\begin{array}{l}\text { Chlorine }-500-1000 \mathrm{ppm} \\
\text { QACs-3-25 ppm }\end{array}$ & & n.i. & {$[135]$} \\
\hline Thymol & $\begin{array}{c}\text { S. enterica serovar } \\
\text { Typhimurium } \\
\text { epidemic phage type } \\
\text { DT193 strain }\end{array}$ & 1250 ppm total eradication & & n.i. & {$[136]$} \\
\hline Ozonated water & $\begin{array}{c}\text { S. Heidelberg } \\
\text { multidrug-resistant } \\
\text { isolated from pigs } \\
\text { (farms) }\end{array}$ & $\mathrm{MIC} 4.4 \mathrm{mg} / \mathrm{L}$ & $\begin{array}{l}\text { Induces changes } \\
\text { in bacterial DNA } \\
\text { after } 10 \mathrm{~min} \\
\text { exposure. }\end{array}$ & n.i. & {$[137]$} \\
\hline $\begin{array}{l}\text { Sodium } \\
\text { hypochlorite } \\
\text { PAA } \\
\text { Chlorhexidine }\end{array}$ & $\begin{array}{l}\text { S. enterica serovar } \\
\text { Minnesota strains } \\
\text { isolated from a } \\
\text { poultry slaughter, } \\
\text { Brazilia }\end{array}$ & $\begin{array}{c}1 \% \text { SH }(100 \%), \\
0.8 \% \text { PAA, and } 1 \% \\
\text { chlorhexidine decrease } \\
\text { bacterial counts by } 3.63 \\
\text { and } 2.96 \mathrm{CFU} / \mathrm{mL}\end{array}$ & n.i. & $\begin{array}{l}\text { Highly virulent due to } \\
\text { factors: avrA, agfA, } \\
\text { lpfA, sodC, and luxS } \\
\text { genes }\end{array}$ & {$[138]$} \\
\hline
\end{tabular}

Novel biocides, such as the black cardamom essential oil, inhibit the biofilm formation in S. Typhimurium JSG 1748, by approximately more than $50 \%$, at concentrations from 0.03 to $0.5 \%$ when they inhibit the quorum-sensing mechanisms of biofilm formation [139]. Other essential oils, such as thymol, were also highlighted to express better antibiofilm potential than benzalkonium chloride against Salmonella enterica serovar Typhimurium DT193 strain [136] at a concentration of 1250 ppm. However, their application on the stainless steel coupons resulted in a 5-log reduction compared to the initial growth inoculum.

\section{Conclusions}

The findings of this review conveyed the broad antibacterial, antiadhesive, and antibiofilm capabilities of various biocidal agents against emerging dangerous pathogenic bacteria. These data could play a lasting indicative role soon due to the description of competent disinfection strategies presented herein. Proper disinfection is a key element of successfully inactivating bacterial and viral pathogens in different agricultural, medical, and agricultural facilities, including the equipment, utensils, and surfaces that urgently require sterilization under the existing pandemic circumstances. The biocontrol measures described in this review emphasize firstly the importance of novel strategies aiming to avoid antibiotic-biocide cross-resistance in pathogenic agents and secondly the necessity of understanding the molecular mechanisms involved.

Author Contributions: Conceptualization, N.C., L.S. and I.B., funding acquisition, N.C.; project administration, N.C.; resources, L.S.; writing-original draft: E.B., I.B. and N.C.; writing-review and editing, F.M., I.P., E.B., L.S., I.B., N.C., M.A. and G.D. All authors have read and agreed to the published version of the manuscript.

Funding: This research was funded by Environtech, grant number 49650.

Institutional Review Board Statement: Not applicable.

Conflicts of Interest: The authors declare no conflict of interest. The funders had no role in the design of the study; in the collection, analyses, or interpretation of data; in the writing of the manuscript; or in the decision to publish the results. 


\section{References}

1. Schirone, M.; Visciano, P.; Tofalo, R.; Suzzi, G. Editorial: Foodborne Pathogens: Hygiene and Safety. Front. Microbiol. 2019, 10, 1974. [CrossRef] [PubMed]

2. Gonzales-Barron, U.; Thébault, A.; Kooh, P.; Watier, L.; Sanaa, M.; Cadavez, V. Strategy for systematic review of observational studies and meta-analysis modelling of risk factors for sporadic foodborne diseases. Microb. Risk Anal. 2021, 17, 100082. [CrossRef]

3. Poole, K. Mechanisms of bacterial biocide and antibiotic resistance. J. Appl. Microbiol. 2002, 92, 55S-64S. [CrossRef] [PubMed]

4. Santajit, S.; Indrawattana, N. Mechanisms of Antimicrobial Resistance in ESKAPE Pathogens. BioMed Res. Int. 2016, $2016,2475067$. [CrossRef] [PubMed]

5. Rice, L.B. Progress and Challenges in Implementing the Research on ESKAPE Pathogens. Infect. Control Hosp. Epidemiol. 2010, 31 , S7-S10. [CrossRef]

6. Meade, E.; Slattery, M.; Garvey, M. Biocidal Resistance in Clinically Relevant Microbial Species: A Major Public Health Risk. Pathogens 2021, 10, 598. [CrossRef]

7. Fernando, S.; Gunasekara, T.; Holton, J. Antimicrobial Nanoparticles: Applications and mechanisms of action. Sri Lankan J. Infect. Dis. 2018, 8, 2. [CrossRef]

8. Fink, J.K. Hydraulic Fracturing Chemicals and Fluids Technology; Gulf Professional Publishing: Oxford, UK, 2013 ; pp. 1-235.

9. McDonnell, G.; Russell, A.D. Antiseptics and Disinfectants: Activity, Action, and Resistance. Clin. Microbiol. Rev. 1999, 12, 147-179. [CrossRef]

10. Gilbert, P.; McBain, A.J.; Bloomfield, S.F. Biocide abuse and antimicrobial resistance: Being clear about the issues J. Antimicrob. Chemother. 2002, 50, 137-139. [CrossRef]

11. Garipov, M.R.; Sabirova, A.E.; Pavelyev, R.S.; Shtyrlin, N.V.; Lisovskaya, S.A.; Bondar, O.V.; Laikov, A.V.; Romanova, J.G.; Bogachev, M.I.; Kayumov, A.R.; et al. Targeting pathogenic fungi, bacteria and fungal-bacterial biofilms by newly synthesized quaternary ammonium derivative of pyridoxine and terbinafine with dual action profile. Bioorg. Chem. 2020, $104,104306$. [CrossRef]

12. Samantaray, P.K.; Kumar, S.; Bose, S. 'Polycation' modified PVDF based antibacterial and antifouling membranes and 'point-of-use supports' for sustainable and effective water decontamination. J. Water Process. Eng. 2020, 38, 101536. [CrossRef]

13. Heydarifard, S.; Taneja, K.; Bhanjana, G.; Dilbaghi, N.; Nazhad, M.M.; Kim, K.-H.; Kumar, S. Modification of cellulose foam paper for use as a high-quality biocide disinfectant filter for drinking water. Carbohydr. Polym. 2018, 181, 1086-1092. [CrossRef] [PubMed]

14. Hughes, L.; Roberts, W.; Johnson, D. The impact of DNA adenine methyltransferase knockout on the development of triclosan resistance and antibiotic cross-resistance in Escherichia coli. Access Microbiol. 2021, 3, 000178. [CrossRef]

15. Mann, R.; Holmes, A.; McNeilly, O.; Cavaliere, R.; Sotiriou, G.A.; Rice, S.A.; Gunawan, C. Evolution of biofilm-forming pathogenic bacteria in the presence of nanoparticles and antibiotic: Adaptation phenomena and cross-resistance. J. Nanobiotechnol. 2021, 19, 291. [CrossRef] [PubMed]

16. Puangseree, J.; Jeamsripong, S.; Prathan, R.; Pungpian, C.; Chuanchuen, R. Resistance to widely-used disinfectants and heavy metals and cross resistance to antibiotics in Escherichia coli isolated from pigs, pork and pig carcass. Food Control 2021, 124, 107892. [CrossRef]

17. Amsalu, A.; Sapula, S.A.; Lopes, M.D.B.; Hart, B.J.; Nguyen, A.H.; Drigo, B.; Turnidge, J.; Leong, L.E.; Venter, H. Efflux PumpDriven Antibiotic and Biocide Cross-Resistance in Pseudomonas aeruginosa Isolated from Different Ecological Niches: A Case Study in the Development of Multidrug Resistance in Environmental Hotspots. Microorganisms 2020, 8, 1647. [CrossRef]

18. Kahrilas, G.A.; Blotevogel, J.; Stewart, P.S.; Borch, T. Biocides in Hydraulic Fracturing Fluids: A Critical Review of Their Usage, Mobility, Degradation, and Toxicity. Environ. Sci. Technol. 2014, 49, 16-32. [CrossRef]

19. Morente, E.O.; Fernández-Fuentes, M.A.; Burgos, M.J.G.; Abriouel, H.; Perez-Pulido, R.; Galvez, A. Biocide tolerance in bacteria Int. J. Food Microbiol. 2013, 162, 13-25. [CrossRef]

20. Balta, I.; Linton, M.; Pinkerton, L.; Kelly, C.; Ward, P.; Stef, L.; Pet, I.; Horablaga, A.; Gundogdu, O.; Corcionivoschi, N. The effect of natural antimicrobials on the Campylobacter coli $\mathrm{T}^{2} \mathrm{SS}^{+/-}$during in vitro infection assays and on their ability to adhere to chicken skin and carcasses. Int. J. Food Microbiol. 2021, 338, 108998. [CrossRef]

21. Tabak, M.; Scher, K.; Hartog, E.; Romling, U.; Matthews, K.R.; Chikindas, M.L.; Yaron, S. Effect of triclosan on Salmonella typhimurium at different growth stages and in biofilms. FEMS Microbiol. Lett. 2007, 267, 200-206. [CrossRef]

22. Balta, I.; Linton, M.; Pinkerton, L.; Kelly, C.; Stef, L.; Pet, I.; Stef, D.; Criste, A.; Gundogdu, O.; Corcionivoschi, N. The effect of natural antimicrobials against Campylobacter spp. and its similarities to Salmonella spp., Listeria spp., Escherichia coli, Vibrio spp., Clostridium spp. and Staphylococcus spp. Food Control 2020, 121, 107745. [CrossRef]

23. Turner, R.J. Metal-based antimicrobial strategies. Microb. Biotechnol. 2017, 10, 1062-1065. [CrossRef] [PubMed]

24. Harrison, J.J.; Ceri, H.; Stremick, C.A.; Turner, R.J. Biofilm susceptibility to metal toxicity. Environ. Microbiol. 2004, 6, 1220-1227. [CrossRef] [PubMed]

25. Pal, C.; Bengtsson-Palme, J.; Kristiansson, E.; Larsson, D.G.J. Co-occurrence of resistance genes to antibiotics, biocides and metals reveals novel insights into their co-selection potential. BMC Genom. 2015, 16, 964. [CrossRef]

26. Piddock, L.J.V. The crisis of no new antibiotics-What is the way forward? Lancet Infect. Dis. 2012, 12, 249-253. [CrossRef] 
27. Kayumov, A.R.; Nureeva, A.A.; Trizna, E.Y.; Gazizova, G.R.; Bogachev, M.; Shtyrlin, N.; Pugachev, M.; Sapozhnikov, S.V.; Shtyrlin, Y. New Derivatives of Pyridoxine Exhibit High Antibacterial Activity against Biofilm-Embedded Staphylococcus Cells. BioMed Res. Int. 2015, 2015, 890968. [CrossRef]

28. Cheng, L.; Zhang, K.; Melo, M.; Weir, M.; Zhou, X.; Xu, H. Anti-biofilm Dentin Primer with Quaternary Ammonium and Silver Nanoparticles. J. Dent. Res. 2012, 91, 598-604. [CrossRef]

29. Tischer, M.; Pradel, G.; Ohlsen, K.; Holzgrabe, U. Quaternary ammonium salts and their antimicrobial potential: Targets or nonspecific interactions? ChemMedChem 2012, 7, 22-31. [CrossRef]

30. Shtyrlin, N.V.; Pugachev, M.V.; Sapozhnikov, S.V.; Garipov, M.R.; Vafina, R.M.; Grishaev, D.Y.; Pavelyev, R.S.; Kazakova, R.R.; Agafonova, M.N.; Iksanova, A.G.; et al. Novel Bis-Ammonium Salts of Pyridoxine: Synthesis and Antimicrobial Properties. Molecules 2020, 25, 4341. [CrossRef]

31. Evans, A.; Kavanagh, K.A. Evaluation of metal-based antimicrobial compounds for the treatment of bacterial pathogens J. Med. Microbiol. 2021, 70, 001363. [CrossRef]

32. Juszkiewicz, M.; Walczak, M.; Woźniakowski, G. Characteristics of selected active substances used in disinfectants and their virucidal activity against ASFV. J. Veter. Res. 2019, 63, 17-25. [CrossRef] [PubMed]

33. Giuliano, C.A.; Rybak, M.J. Efficacy of Triclosan as an Antimicrobial Hand Soap and Its Potential Impact on Antimicrobial Resistance: A Focused Review. Pharmacother. J. Hum. Pharmacol. Drug Ther. 2015, 35, 328-336. [CrossRef] [PubMed]

34. Macri, D. Worldwide Use of Triclosan: Can Dentistry Do Without this Antimicrobial? Contemp. Clin. Dent. 2017, 8, 7-8. [CrossRef] [PubMed]

35. Saleh, S.; Haddadin, R.; Baillie, S.; Collier, P. Triclosan-An update. Lett. Appl. Microbiol. 2010, 52, 87-95. [CrossRef]

36. Köhler, A.T.; Rodloff, A.C.; Labahn, M.; Reinhardt, M.; Truyen, U.; Speck, S. Efficacy of sodium hypochlorite against multidrugresistant Gram-negative bacteria. J. Hosp. Infect. 2018, 100, e40-e46. [CrossRef]

37. Kampf, G.; Todt, D.; Pfaender, S.; Steinmann, E. Persistence of coronaviruses on inanimate surfaces and their inactivation with biocidal agents. J. Hosp. Infect. 2020, 104, 246-251, Corrigendum in J. Hosp. Infect. 2020, 105, 587. [CrossRef]

38. Vereshchagin, A.; Frolov, N.; Egorova, K.; Seitkalieva, M.; Ananikov, V. Quaternary Ammonium Compounds (QACs) and Ionic Liquids (ILs) as Biocides: From Simple Antiseptics to Tunable Antimicrobials. Int. J. Mol. Sci. 2021, 22, 6793. [CrossRef]

39. Shaban, S.M.; Saied, A.; Tawfik, S.M.; Abd-Elaal, A.; Aiad, I. Corrosion inhibition and Biocidal effect of some cationic surfactants based on Schiff base. J. Ind. Eng. Chem. 2013, 19, 2004-2009. [CrossRef]

40. Borges, A.; Abreu, A.C.; Dias, C.; Saavedra, M.J.; Borges, F.; Simões, M. New Perspectives on the Use of Phytochemicals as an Emergent Strategy to Control Bacterial Infections Including Biofilms. Molecules 2016, 21, 877. [CrossRef]

41. Shin, S.-A.; Joo, B.J.; Lee, J.; Ryu, G.; Han, M.; Kim, W.-Y.; Park, H.H.; Lee, J.; Lee, C.S. Phytochemicals as Anti-Inflammatory Agents in Animal Models of Prevalent Inflammatory Diseases. Molecules 2020, 25, 5932. [CrossRef]

42. Paulus, W. Directory of Microbicides for the Protection of Materials: A Handbook; Springer Science \& Business Media: Berlin, Germany, 2005.

43. Denyer, S.P.; Stewart, G.S.A.B. Mechanisms of action of disinfectants. Int. Biodeterior. Biodegrad. 1998, 41, 261-268. [CrossRef]

44. Araújo, P.; Lemos, M.; Mergulhão, F.; Melo, L.; Simões, M. Antimicrobial resistance to disinfectants in biofilms. Sci. Against Microb. Pathog. Commun. Curr. Res. Technol. Adv. 2011, 3, 826-834.

45. Mitra, D.; Kang, E.-T.; Neoh, K.G. Antimicrobial Copper-Based Materials and Coatings: Potential Multifaceted Biomedical Applications. ACS Appl. Mater. Interfaces 2019, 12, 21159-21182. [CrossRef]

46. Jamaati, H.; Mortaz, E.; Pajouhi, Z.; Folkerts, G.; Movassaghi, M.; Moloudizargari, M.; Adcock, I.M.; Garssen, J. Nitric Oxide in the Pathogenesis and Treatment of Tuberculosis. Front. Microbiol. 2017, 8, 2008. [CrossRef] [PubMed]

47. Kalantari, K.; Afifi, A.M.; Jahangirian, H.; Webster, T.J. Biomedical applications of chitosan electrospun nanofibers as a green polymer-Review. Carbohydr. Polym. 2018, 207, 588-600. [CrossRef]

48. Jiao, Y.; Niu, L.-N.; Ma, S.; Li, J.; Tay, F.R.; Chen, J.-H. Quaternary ammonium-based biomedical materials: State-of-the-art, toxicological aspects and antimicrobial resistance. Prog. Polym. Sci. 2017, 71, 53-90. [CrossRef]

49. Chai, D.; Liu, W.; Hao, X.; Wang, H.; Wang, H.; Hao, Y.; Gao, Y.; Qu, H.; Wang, L.; Dong, A.; et al. Mussel-inspired synthesis of magnetic N-Halamine nanoparticles for antibacterial recycling. Colloids Interface Sci. Commun. 2020, 39, 100320. [CrossRef]

50. Qian, Y.X.; Zhang, D.F.; Wu, Y.M.; Chen, Q.; Liu, R.H. The design, synthesis and biological activity study of nylon-3 polymers as mimics of host defense peptides. Acta Polym. Sin. 2016, 10, 1300-1311.

51. Ding, X.; Duan, S.; Ding, X.; Liu, R.; Xu, F.J. Versatile Antibacterial Materials: An Emerging Arsenal for Combatting Bacterial Pathogens. Adv. Funct. Mater. 2018, 28, 1802140. [CrossRef]

52. Thallinger, B.; Prasetyo, E.N.; Nyanhongo, G.S.; Guebitz, G.M. Antimicrobial enzymes: An emerging strategy to fight microbes and microbial biofilms. Biotechnol. J. 2013, 8, 97-109. [CrossRef]

53. Dong, A.; Wang, Y.-J.; Gao, Y.; Gao, T.; Gao, G. Chemical Insights into Antibacterial N-Halamines. Chem. Rev. 2017, 117, 4806-4862. [CrossRef] [PubMed]

54. Dong, J.J.; Muszanska, A.; Xiang, F.; Falkenberg, R.; Van De Belt-Gritter, B.; Loontjens, T.J.A. Contact Killing of Gram-Positive and Gram-Negative Bacteria on PDMS Provided with Immobilized Hyperbranched Antibacterial Coatings. Langmuir 2019, 35, 14108-14116. [CrossRef] [PubMed]

55. Russell, A. Biocide use and antibiotic resistance: The relevance of laboratory findings to clinical and environmental situations. Lancet Infect. Dis. 2003, 3, 794-803. [CrossRef] 
56. Gilbert, P.; McBain, A.J. Potential Impact of Increased Use of Biocides in Consumer Products on Prevalence of Antibiotic Resistance. Clin. Microbiol. Rev. 2003, 16, 189-208. [CrossRef] [PubMed]

57. Cloete, T. Resistance mechanisms of bacteria to antimicrobial compounds. Int. Biodeterior. Biodegrad. 2003, 51, 277-282. [CrossRef]

58. Forbes, S.; Cowley, N.; Humphreys, G.; Mistry, H.; Amézquita, A.; McBain, A.J. Formulation of Biocides Increases Antimicrobial Potency and Mitigates the Enrichment of Nonsusceptible Bacteria in Multispecies Biofilms. Appl. Environ. Microbiol. 2017, 83, e03054-16. [CrossRef]

59. White, D.G.; McDermott, P.F. Biocides, drug resistance and microbial evolution. Curr. Opin. Microbiol. 2001, 4, 313-317. [CrossRef]

60. Fleitas, O.; Franco, O.L. Induced Bacterial Cross-Resistance toward Host Antimicrobial Peptides: A Worrying Phenomenon. Front. Microbiol. 2016, 7, 381. [CrossRef]

61. Calvert, M.B.; Jumde, V.R.; Titz, A. Pathoblockers or antivirulence drugs as a new option for the treatment of bacterial infections. Beilstein J. Org. Chem. 2018, 14, 2607-2617. [CrossRef]

62. Davin-Regli, A.; Pagès, J.M. Cross-resistance between biocides and antimicrobials: An emerging question. Rev. Sci. Tech. 2012, 31, 89-104. [CrossRef]

63. Sonbol, F.I.; El-Banna, T.E.; El-Aziz, A.A.; El-Ekhnawy, E. Impact of triclosan adaptation on membrane properties, efflux and antimicrobial resistance of Escherichia coli clinical isolates. J. Appl. Microbiol. 2018, 126, 730-739. [CrossRef] [PubMed]

64. Khan, A.; Miller, W.; Arias, C.A. Mechanisms of antimicrobial resistance among hospital-associated pathogens. Expert Rev. Anti-Infect. Ther. 2018, 16, 269-287. [CrossRef] [PubMed]

65. Baker-Austin, C.; Wright, M.S.; Stepanauskas, R.; McArthur, J. Co-selection of antibiotic and metal resistance. Trends Microbiol. 2006, 14, 176-182. [CrossRef] [PubMed]

66. Guentzel, M.N. Escherichia, Klebsiella, Enterobacter, Serratia, Citrobacterv, and Proteus. In Medical Microbiology; Baron, S., Ed.; University of Texas Medical Branch at Galveston: Galveston, TX, USA, 1996.

67. Stratakos, A.C.; Sima, F.; Ward, P.; Linton, M.; Kelly, C.; Pinkerton, L.; Stef, L.; Pet, I.; Corcionivoschi, N. The in vitro effect of carvacrol, a food additive, on the pathogenicity of O157 and non-O157 Shiga-toxin producing Escherichia coli. Food Control 2017, 84, 290-296. [CrossRef]

68. Foglarova, M.; Prokop, J.; Milichovsky, M. Oxidized cellulose: An application in the form of sorption filter materials. J. Appl. Polym. Sci. 2009, 112, 669-678. [CrossRef]

69. Lee, A.; Elam, J.W.; Darling, S.B. Membrane materials for water purification: Design, development, and application Environ. Sci. Water Res. Technol. 2016, 2, 17-42. [CrossRef]

70. Meireles, A.; Ferreira, C.; Melo, L.; Simões, M. Comparative stability and efficacy of selected chlorine-based biocides against Escherichia coli in planktonic and biofilm states. Food Res. Int. 2017, 102, 511-518. [CrossRef]

71. Smirnova, M.; Kolodkin, N.; Kolobov, A.; Afonin, V.; Afonina, I.; Stefanenko, L.; Shpen', V.; Shamova, O. Indolicidin analogs with broad-spectrum antimicrobial activity and low hemolytic activity. Peptides 2020, 132, 170356. [CrossRef]

72. Ali, S.; Khan, S.J.; Allan, R.; Hashmi, I. Biocidal potential of electrochemically activated solutions (ECAS) against Aeromonas sp. Enterobacter sp. and Escherichia coli in tap water. J. Water Process Eng. 2020, 36, 101328. [CrossRef]

73. Fu, Y.; Wang, F.; Sheng, H.; Xu, M.; Liang, Y.; Bian, Y.; Hashsham, S.A.; Jiang, X.; Tiedje, J.M. Enhanced antibacterial activity of magnetic biochar conjugated quaternary phosphonium salt. Carbon 2020, 163, 360-369. [CrossRef]

74. Campo, N.; De Flora, C.; Maffettone, R.; Manoli, K.; Sarathy, S.; Santoro, D.; Gonzalez-Olmos, R.; Auset, M. Inactivation kinetics of antibiotic resistant Escherichia coli in secondary wastewater effluents by peracetic and performic acids. Water Res. 2019, 169, 115227. [CrossRef] [PubMed]

75. Zarrella, I.; Falivene, L.; Galiakberov, V.; Fiorentino, A.; Cucciniello, R.; Motta, O.; Rizzo, L.; Krasnogorskaya, N.; Proto, A. Effect of the aqueous matrix on the inactivation of E. coli by permaleic acid. Sci. Total Environ. 2020, 767, 144395. [CrossRef] [PubMed]

76. Hameed, S.; Wang, Y.; Zhao, L.; Xie, L.; Ying, Y. Shape-dependent significant physical mutilation and antibacterial mechanisms of gold nanoparticles against foodborne bacterial pathogens (Escherichia coli, Pseudomonas aeruginosa and Staphylococcus aureus) at lower concentrations. Mater. Sci. Eng. C 2019, 108, 110338. [CrossRef] [PubMed]

77. Theofilou, S.; Antoniou, C.; Potamiti, L.; Hadjisavvas, A.; Panayiotidis, M.; Savva, P.; Costa, C.; Fotopoulos, V. Immobilized Ag-nanoparticles (iNPs) for environmental applications: Elucidation of immobilized silver-induced inhibition mechanism of Escherichia coli. J. Environ. Chem. Eng. 2021, 9, 106001. [CrossRef]

78. Santo, C.E.; Taudte, N.; Nies, D.H.; Grass, G. Contribution of Copper Ion Resistance to Survival of Escherichia coli on Metallic Copper Surfaces. Appl. Environ. Microbiol. 2008, 74, 977-986. [CrossRef] [PubMed]

79. Manoharan, R.K.; Gangadaran, P.; Ayyaru, S.; Ahn, B.-C.; Ahn, Y.-H. Self-healing functionalization of sulfonated hafnium oxide and copper oxide nanocomposite for effective biocidal control of multidrug-resistant bacteria. New J. Chem. 2021, 45, $9506-9517$. [CrossRef]

80. Si, Y.; Zhang, Z.; Wu, W.; Fu, Q.; Huang, K.; Nitin, N.; Ding, B.; Sun, G. Daylight-driven rechargeable antibacterial and antiviral nanofibrous membranes for bioprotective applications. Sci. Adv. 2018, 4, eaar5931. [CrossRef]

81. Ciofu, O.; Tolker-Nielsen, T. Tolerance and Resistance of Pseudomonas aeruginosa Biofilms to Antimicrobial Agents-How P. aeruginosa Can Escape Antibiotics. Front. Microbiol. 2019, 10, 913. [CrossRef]

82. Høiby, N.; Ciofu, O.; Bjarnsholt, T. Pseudomonas aeruginosa biofilms in cystic fibrosis. Futur. Microbiol. 2010, 5, 1663-1674. [CrossRef] 
83. Castro, M.S.R.; Fernandes, M.D.S.; Kabuki, D.Y.; Kuaye, A.Y. Modelling Pseudomonas fluorescens and Pseudomonas aeruginosa biofilm formation on stainless steel surfaces and controlling through sanitisers. Int. Dairy J. 2020, 114, 104945. [CrossRef]

84. Batista, W.R.; Fernandes, F.C.; Neves, M.H.; Nascimento, T.; Lopes, R.; Lopes, C.; Ziegler, G.P.; Figueroa, B.M.S.; Sparks, D.; Fontaine, D.; et al. Synthetic lipids as a biocide candidate for disinfection of ballast water. Mar. Pollut. Bull. 2018, 137, 702-710. [CrossRef] [PubMed]

85. Fernandes, S.; Gomes, I.B.; Simões, M. Antimicrobial activity of glycolic acid and glyoxal against Bacillus cereus and Pseudomonas fluorescens. Food Res. Int. 2020, 136, 109346. [CrossRef]

86. Goodarzi, R.; Yousefimashouf, R.; Taheri, M.; Nouri, F.; Asghari, B. Susceptibility to biocides and the prevalence of biocides resistance genes in clinical multidrug-resistant Pseudomonas aeruginosa isolates from Hamadan, Iran. Mol. Biol. Rep. 2021, 48, 5275-5281. [CrossRef]

87. Moshynets, O.V.; Baranovskyi, T.P.; Iungin, O.S.; Kysil, N.P.; Metelytsia, L.O.; Pokholenko, I.; Potochilova, V.V.; Potters, G.; Rudnieva, K.L.; Rymar, S.Y.; et al. eDNA Inactivation and Biofilm Inhibition by the PolymericBiocide Polyhexamethylene Guanidine Hydrochloride (PHMG-Cl). Int. J. Mol. Sci. 2022, 23, 731. [CrossRef] [PubMed]

88. Torres, M.D.T.; Voskian, S.; Brown, P.; Liu, A.; Lu, T.K.; Hatton, T.A.; De La Fuente-Nunez, C. Coatable and Resistance-Proof Ionic Liquid for Pathogen Eradication. ACS Nano 2021, 15, 966-978. [CrossRef] [PubMed]

89. Rendueles, O. Deciphering the role of the capsule of Klebsiella pneumoniae during pathogenesis: A cautionary tale. Mol. Microbiol. 2020, 113, 883-888. [CrossRef] [PubMed]

90. Ryan, K.J.; Ray, C.G. Sherris Medical Microbiology; Mcgraw-Hill: New York, NY, USA, 2003.

91. Bagley, S.T. Habitat Association of Klebsiella Species. Infect. Control 1985, 6, 52-58. [CrossRef] [PubMed]

92. Perez-Palacios, P.; Gual-De-Torrella, A.; Delgado-Valverde, M.; Oteo-Iglesias, J.; Hidalgo-Díaz, C.; Pascual, A.; Fernández-Cuenca, F. Transfer of plasmids harbouring blaOXA-48-like carbapenemase genes in biofilm-growing Klebsiella pneumoniae: Effect of biocide exposure. Microbiol. Res. 2021, 254, 126894. [CrossRef] [PubMed]

93. Morante, J.; Quispe, A.M.; Ymaña, B.; Moya-Salazar, J.; Luque, N.; Soza, G.; Chirinos, M.R.; Pons, M.J. Tolerance to disinfectants (chlorhexidine and isopropanol) and its association with antibiotic resistance in clinically-related Klebsiella pneumoniae isolates. Pathog. Glob. Health 2021, 115, 53-60. [CrossRef] [PubMed]

94. Vaidya, M.Y.; McBain, A.J.; Butler, J.; Banks, C.E.; Whitehead, K.A. Antimicrobial Efficacy and Synergy of Metal Ions against Enterococcus faecium, Klebsiella pneumoniae and Acinetobacter baumannii in Planktonic and Biofilm Phenotypes. Sci. Rep. 2017, 7, 5911. [CrossRef]

95. Mohammed, A.N. Resistance of bacterial pathogens to calcium hypochlorite disinfectant and evaluation of the usability of treated filter paper impregnated with nanosilver composite for drinking water purification. J. Glob. Antimicrob. Resist. 2018, 16, 28-35. [CrossRef] [PubMed]

96. Wand, M.E.; Jamshidi, S.; Bock, L.; Rahman, K.M.; Sutton, J.M. SmvA is an important efflux pump for cationic biocides in Klebsiella pneumoniae and other Enterobacteriaceae. Sci. Rep. 2019, 9, 1344. [CrossRef] [PubMed]

97. Ozturk, A.; Güzel, Ö.T.; Abdulmajed, O.; Erdoğan, M.; Kozan, R.; Çağlar, K.; Kalkanc1, A. Evaluation of the bactericidal activity of some disinfectant agents against carbapenem-resistant Klebsiella pneumoniae isolates. Int. J. Environ. Health Eng. $2020,9,17$.

98. Tang, Y.; Nielsen, L.N.; Hvitved, A.; Haaber, J.K.; Wirtz, C.; Andersen, P.S.; Larsen, J.; Wolz, C.; Ingmer, H. Commercial Biocides Induce Transfer of Prophage $\Phi 13$ from Human Strains of Staphylococcus aureus to Livestock CC398. Front. Microbiol. 2017, 8, 2418. [CrossRef] [PubMed]

99. Price, L.B.; Stegger, M.; Hasman, H.; Aziz, M.; Larsen, J.; Andersen, P.S.; Pearson, T.; Waters, A.E.; Foster, J.T.; Schupp, J.; et al. Staphylococcus aureus CC398: Host Adaptation and Emergence of Methicillin Resistance in Livestock. mBio 2012, 3, e00305-11. [CrossRef]

100. Sabry, W.; Al-Dakhakhni, M.Y.S.; Al-Hoseiny, I.M.; Tawab, R.A.R.A. Detection of Biocides Resistance Genes among Clinical Isolates of Both Methicillin-Resistant and Methicillin-Sensitive Strains of Staphylococcus aureus. Int. J. Med. Arts 2021, 3, 1602-1610. [CrossRef]

101. Kernberger-Fischer, I.A.; Krischek, C.; Strommenger, B.; Fiegen, U.; Beyerbach, M.; Kreienbrock, L.; Klein, G.; Kehrenberg, C. Susceptibility of Methicillin-Resistant and -Susceptible Staphylococcus aureus Isolates of Various Clonal Lineages from Germany to Eight Biocides. Appl. Environ. Microbiol. 2018, 84, e00799-18. [CrossRef]

102. Manukumar, H.M.; Chandrasekhar, B.; Rakesh, K.P.; Ananda, A.P.; Nandhini, M.; Lalitha, P.; Sumathi, S.; Qinb, H.-L.; Umesha, S. Novel T-C@AgNPs mediated biocidal mechanism against biofilm associated methicillin-resistant Staphylococcus aureus (BapMRSA) 090, cytotoxicity and its molecular docking studies. Medchemcomm 2017, 8, 2181-2194. [CrossRef]

103. Manukumar, H.; Yashwanth, B.; Umesha, S.; Rao, J.V. Biocidal mechanism of green synthesized thyme loaded silver nanoparticles (GTAgNPs) against immune evading tricky methicillin-resistant Staphylococcus aureus 090 (MRSA090) at a homeostatic environment. Arab. J. Chem. 2020, 13, 1179-1197. [CrossRef]

104. Nickel, R.; Kazemian, M.R.; Wroczynskyj, Y.; Liu, S.; van Lierop, J. Exploiting shape-selected iron oxide nanoparticles for the destruction of robust bacterial biofilms-Active transport of biocides via surface charge and magnetic field control. Nanoscale 2020, 12, 4328-4333. [CrossRef]

105. Marbach, H.; Vizcay-Barrena, G.; Memarzadeh, K.; Otter, J.A.; Pathak, S.; Allaker, R.P.; Harvey, R.D.; Edgeworth, J.D. Tolerance of MRSA ST239-TW to chlorhexidine-based decolonization: Evidence for keratinocyte invasion as a mechanism of biocide evasion. J. Infect. 2018, 78, 119-126. [CrossRef] [PubMed] 
106. Conceição, T.; de Lencastre, H.; Aires-De-Sousa, M. Prevalence of biocide resistance genes and chlorhexidine and mupirocin non-susceptibility in Portuguese hospitals during a 31-year period (1985-2016). J. Glob. Antimicrob. Resist. 2020, 24, 169-174. [CrossRef] [PubMed]

107. Worthing, K.; Marcus, A.; Abraham, S.; Trott, D.J.; Norris, J.M. Qac genes and biocide tolerance in clinical veterinary methicillinresistant and methicillin-susceptible Staphylococcus aureus and Staphylococcus pseudintermedius. Veter.-Microbiol. 2018, 216, 153-158. [CrossRef] [PubMed]

108. Hoque, J.; Haldar, J. Direct Synthesis of Dextran-Based Antibacterial Hydrogels for Extended Release of Biocides and Eradication of Topical Biofilms. ACS Appl. Mater. Interfaces 2017, 9, 15975-15985. [CrossRef] [PubMed]

109. Oxaran, V.; Dittmann, K.K.; Lee, S.H.I.; Chaul, L.T.; de Oliveira, C.A.F.; Corassin, C.H.; Alves, V.F.; De Martinis, E.C.P.; Gram, L. Behavior of Foodborne Pathogens Listeria monocytogenes and Staphylococcus aureus in Mixed-Species Biofilms Exposed to Biocides. Appl. Environ. Microbiol. 2018, 84. [CrossRef] [PubMed]

110. Rodríguez-López, P.; Rodríguez-Herrera, J.J.; Vázquez-Sánchez, D.; Cabo, M.L. Current Knowledge on Listeria monocytogenes Biofilms in Food-Related Environments: Incidence, Resistance to Biocides, Ecology and Biocontrol. Foods 2018, 7, 85. [CrossRef]

111. Stratakos, A.C.; Ijaz, U.Z.; Ward, P.; Linton, M.; Kelly, C.; Pinkerton, L.; Scates, P.; McBride, J.; Pet, I.; Criste, A.; et al. In vitro and in vivo characterisation of Listeria monocytogenes outbreak isolates. Food Control 2020, 107. [CrossRef]

112. Duze, S.T.; Marimani, M.; Patel, M. Tolerance of Listeria monocytogenes to biocides used in food processing environments. Food Microbiol. 2021, 97, 103758. [CrossRef]

113. Roedel, A.; Dieckmann, R.; Brendebach, H.; Hammerl, J.A.; Kleta, S.; Noll, M.; Al Dahouk, S.; Vincze, S. Biocide-Tolerant Listeria monocytogenes Isolates from German Food Production Plants Do Not Show Cross-Resistance to Clinically Relevant Antibiotics. Appl. Environ. Microbiol. 2019, 85, e01253-19. [CrossRef]

114. Guérin, A.; Bridier, A.; Le Grandois, P.; Sévellec, Y.; Palma, F.; Félix, B.; Roussel, S.; Soumet, C.; LISTADAPT Study Group. Exposure to Quaternary Ammonium Compounds Selects Resistance to Ciprofloxacin in Listeria monocytogenes. Pathogens 2021, 10, 220. [CrossRef]

115. Noll, M.; Trunzer, K.; Vondran, A.; Vincze, S.; Dieckmann, R.; Al Dahouk, S.; Gold, C. Benzalkonium Chloride Induces a VBNC State in Listeria monocytogenes. Microorganisms 2020, 8, 184. [CrossRef] [PubMed]

116. Kropac, A.; Eshwar, A.K.; Stephan, R.; Tasara, T. New Insights on the Role of the pLMST6 Plasmid in Listeria monocytogenes Biocide Tolerance and Virulence. Front. Microbiol. 2019, 10, 1538. [CrossRef] [PubMed]

117. Mafuna, T.; Matle, I.; Magwedere, K.; Pierneef, R.E.; Reva, O.N. Whole Genome-Based Characterization of Listeria monocytogenes Isolates Recovered from the Food Chain in South Africa. Front. Microbiol. 2021, 12, 669287. [CrossRef] [PubMed]

118. Dygico, L.K.; Gahan, C.G.; Grogan, H.; Burgess, C.M. Examining the efficacy of mushroom industry biocides on Listeria monocytogenes biofilm. J. Appl. Microbiol. 2020, 130, 1106-1116. [CrossRef]

119. Luque-Sastre, L.; Fox, E.; Jordan, K.; Fanning, S. A Comparative Study of the Susceptibility of Listeria Species to Sanitizer Treatments When Grown under Planktonic and Biofilm Conditions. J. Food Prot. 2018, 81, 1481-1490. [CrossRef]

120. Haubert, L.; Zehetmeyr, M.L.; Da Silva, W.P. Resistance to benzalkonium chloride and cadmium chloride in Listeria monocytogenes isolates from food and food-processing environments in southern Brazil. Can. J. Microbiol. 2019, 65, 429-435. [CrossRef]

121. Rodríguez-Melcón, C.; Capita, R.; Rodríguez-Jerez, J.J.; Martínez-Suárez, J.V.; Alonso-Calleja, C. Effect of Low Doses of Disinfectants on the Biofilm-Forming Ability of Listeria monocytogenes. Foodborne Pathog. Dis. 2019, 16, 262-268. [CrossRef]

122. Vázquez-Sánchez, D.; Galvão, J.A.; Oetterer, M. Contamination sources, serogroups, biofilm-forming ability and biocide resistance of Listeria monocytogenes persistent in tilapia-processing facilities. J. Food Sci. Technol. 2017, 54, 3867-3879. [CrossRef]

123. Rodríguez-Melcón, C.; Riesco-Peláez, F.; Fernández, M.D.C.G.; Alonso-Calleja, C.; Capita, R. Susceptibility of Listeria monocytogenes planktonic cultures and biofilms to sodium hypochlorite and benzalkonium chloride. Food Microbiol. 2019, 82, 533-540. [CrossRef]

124. Møretrø, T.; Schirmer, B.C.; Heir, E.; Fagerlund, A.; Hjemli, P.; Langsrud, S. Tolerance to quaternary ammonium compound disinfectants may enhance growth of Listeria monocytogenes in the food industry. Int. J. Food Microbiol. 2017, 241, 215-224. [CrossRef]

125. López-Alonso, V.; Ortiz, S.; Corujo, A.; Martínez-Suárez, J.V. Analysis of Benzalkonium Chloride Resistance and Potential Virulence of Listeria monocytogenes Isolates Obtained from Different Stages of a Poultry Production Chain in Spain. J. Food Prot. 2020, 83, 443-451. [CrossRef] [PubMed]

126. Karki, A.B.; Wells, H.; Fakhr, M.K. Retail liver juices enhance the survivability of Campylobacter jejuni and Campylobacter coli at low temperatures. Sci. Rep. 2019, 9, 2733. [CrossRef] [PubMed]

127. Beier, R.C.; Byrd, J.A.; Andrews, K.; Caldwell, D.; Crippen, T.L.; Anderson, R.C.; Nisbet, D.J. Disinfectant and antimicrobial susceptibility studies of the foodborne pathogen Campylobacter jejuni isolated from the litter of broiler chicken houses. Poult. Sci. 2020, 100, 1024-1033. [CrossRef] [PubMed]

128. Beier, R.C.; Harvey, R.B.; Hernandez, C.A.; Andrews, K.; Droleskey, R.E.; Hume, M.E.; Davidson, M.K.; Bodeis-Jones, S.; Young, S.; Anderson, R.C.; et al. Disinfectant and Antimicrobial Susceptibility Profiles of Campylobacter coli Isolated in 1998 to 1999 and 2015 from Swine and Commercial Pork Chops. J. Food Sci. 2019, 84, 1501-1512. [CrossRef] [PubMed]

129. Muhandiramlage, G.K.; McWhorter, A.R.; Chousalkar, K.K. Chlorine Induces Physiological and Morphological Changes on Chicken Meat Campylobacter Isolates. Front. Microbiol. 2020, 11, 503. [CrossRef] 
130. Talukdar, P.K.; Turner, K.L.; Crockett, T.M.; Lu, X.; Morris, C.F.; Konkel, M.E. Inhibitory Effect of Puroindoline Peptides on Campylobacter jejuni Growth and Biofilm Formation. Front. Microbiol. 2021, 12, 702762. [CrossRef]

131. Paliy, A.B.T.; Stegniy, V.I.; Bolotin, K.A.; Rodionova, T.M.; Ihnatieva, O.M.; Bobrytska, V.Y.; Kushnir, O.V.; Matsenko, L.L.; Kushch, V.S.; Bulavina, O.V.; et al. Study of disinfectants bactericidal properties against Campylobacter spp. at sub-zero temperatures. Ukranina J. Eclogy 2021, 11, 391-398.

132. Sibanda, N.; McKenna, A.; Richmond, A.; Ricke, S.C.; Callaway, T.; Stratakos, A.C.; Gundogdu, O.; Corcionivoschi, N. A Review of the Effect of Management Practices on Campylobacter Prevalence in Poultry Farms. Front. Microbiol. 2018, 9, 2002. [CrossRef]

133. European Food Safety Authority (EFSA). ECDC (European Food Safety Authority and European Centre for Disease Prevention and Control) The European Union One Health 2018 Zoonoses Report. EFSA J. 2021, 19, e06406.

134. Lamas, A.; Miranda, J.; Regal, P.; Vazquez, B.; Franco, C.M.; Cepeda, A. A comprehensive review of non-enterica subspecies of Salmonella enterica. Microbiol. Res. 2018, 206, 60-73. [CrossRef]

135. Obe, T.; Nannapaneni, R.; Schilling, W.; Zhang, L.; Kiess, A. Antimicrobial tolerance, biofilm formation, and molecular characterization of Salmonella isolates from poultry processing equipment. J. Appl. Poult. Res. 2021, 30, 100195. [CrossRef]

136. Strantzali, D.; Kostoglou, D.; Perikleous, A.; Zestas, M.; Ornithopoulou, S.; Dubois-Brissonnet, F.; Giaouris, E. Comparative assessment of the disinfection effectiveness of thymol and benzalkonium chloride against adapted and non-adapted to thymol biofilm cells of a Salmonella typhimurium epidemic phage type DT193 strain. Food Control 2021, 129, 108239. [CrossRef]

137. Nascente, E.D.P.; Rauecker, N.; Teles, A.V.; Divino, L.D.D.A.; Chagas, S.R.; Elias, L.M.; Matos, M.P.C.; Andrade, M.A.; Pascoal, L.M. Inactivation of Multidrug-Resistant Salmonella Heidelberg Isolated from Pigs by Ozonated Water under Different Conditions. Ozone: Sci. Eng. 2021, 1-9. [CrossRef]

138. De Melo, R.T.; dos Reis Cardoso, T.; Peres PA, B.M.; Braz, R.F.; Monteiro, G.P.; Rossi, D.A. Salmonella enterica Serovar Minnesota Biofilms, Susceptibility to Biocides, and Molecular Characterization. Pathogens 2021, 10, 581. [CrossRef] [PubMed]

139. Algburi, A.; Asghar, A.; Huang, Q.; Mustfa, W.; Javed, H.U.; Zehm, S.; Chikindas, M.L. Black cardamom essential oil prevents Escherichia coli O157:H7 and Salmonella typhimurium JSG 1748 biofilm formation through inhibition of quorum sensing. J. Food Sci. Technol. 2021, 58, 3183-3191. 